\title{
Facile Access to Polysubstituted Indoles via a Cascade Cu-Catalyzed Arylation-Condensation Process
}

\author{
Yu Chen, ${ }^{1}$ Xiaoan $\mathrm{Xie}^{1}$ and Dawei $\mathrm{Ma}^{2 *}$ \\ ${ }^{1}$ Department of Chemistry, Fudan University, Shanghai 200433, China, \\ ${ }^{2}$ State Key Laboratory of Bioorganic and Natural Products Chemistry, Shanghai \\ Institute of Organic Chemistry, Chinese Academy of Sciences, 354 Fenglin Lu, \\ Shanghai 200032, China \\ E-mail:madw@mail.sioc.ac.cn
}

Supporting Information

\section{Table of Contents}

Copies of ${ }^{1} \mathrm{H}$ NMR and ${ }^{13} \mathrm{C}$ NMR spectrum of $7 \mathbf{a}-7 \mathbf{v}---------------------------S 2-S 43$

Copies of ${ }^{1} \mathrm{H}$ NMR and ${ }^{13} \mathrm{C}$ NMR spectrum of $9 \mathbf{a}-9 \mathbf{b}---------------------------S 44-S 47$ 


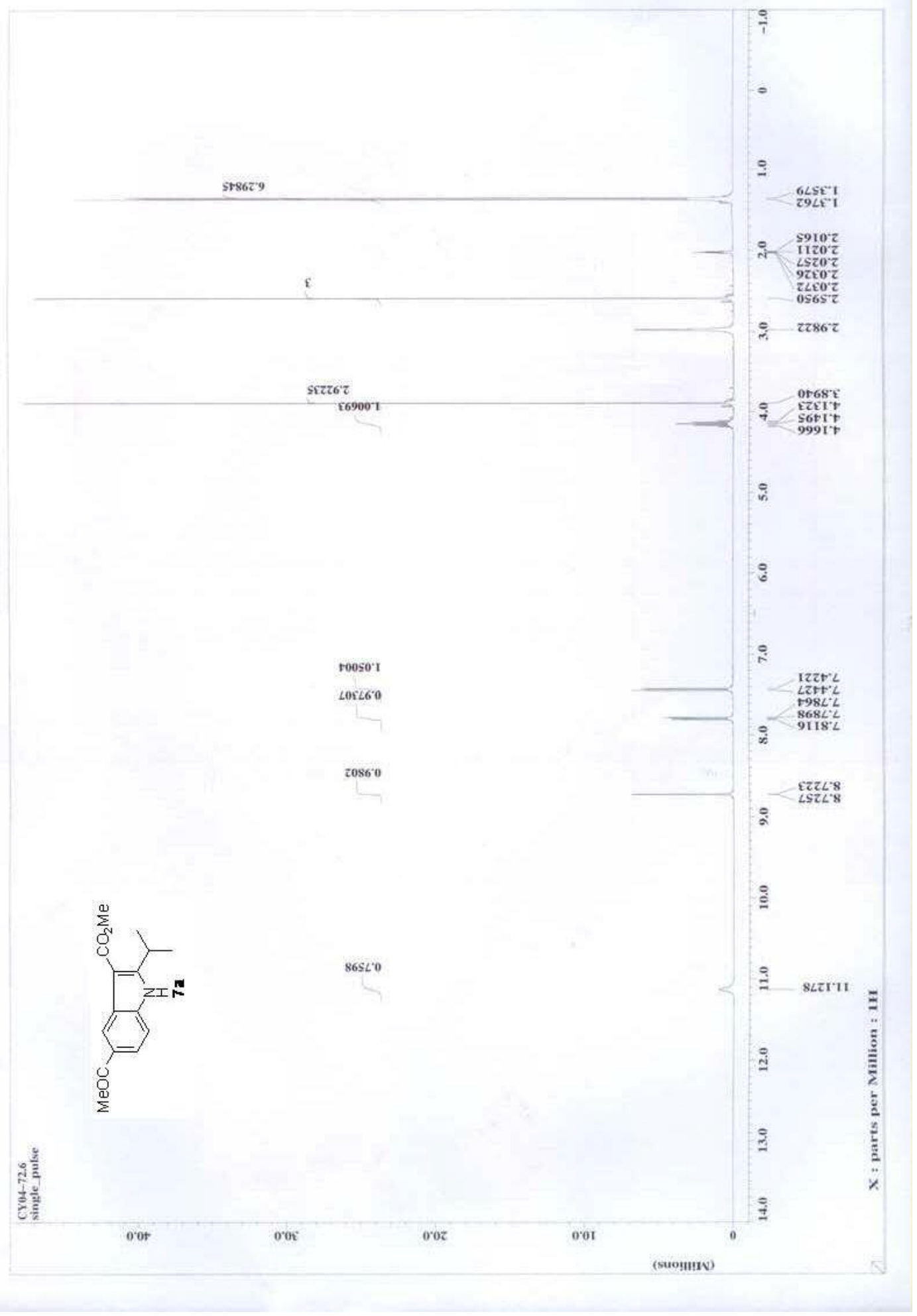


7
$\vdots$
0
0

78912

$\varepsilon<9$ ' 92

88: OE

576. 09

$20 L 9 L$
$020: L L \longrightarrow$

gEE $\angle L$

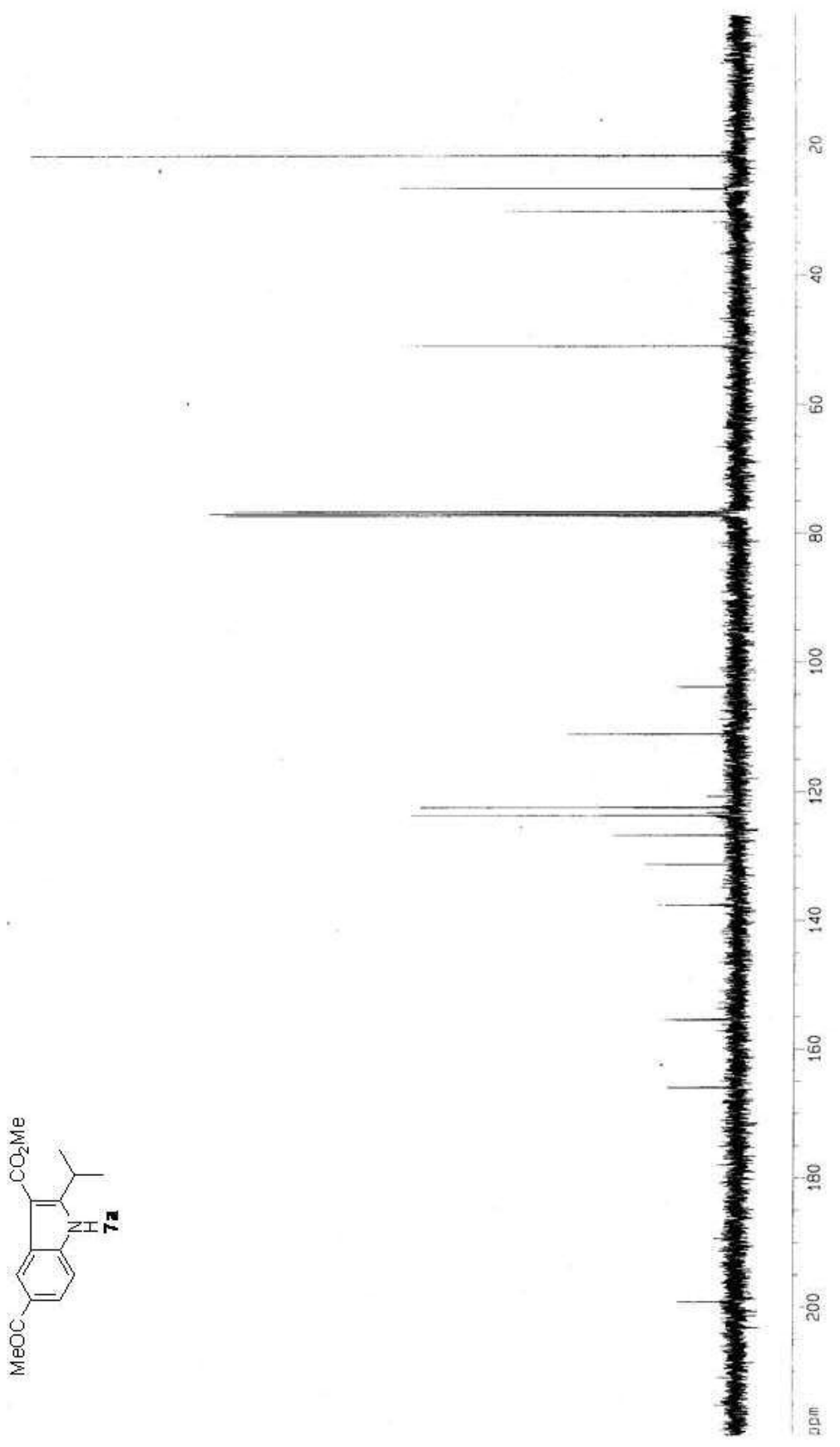

wdd

EEV ट5t-

र99 Eटl

LLC IE!

It $\angle E !$

VIV SGI -

I96 991

$98066 t \ldots$

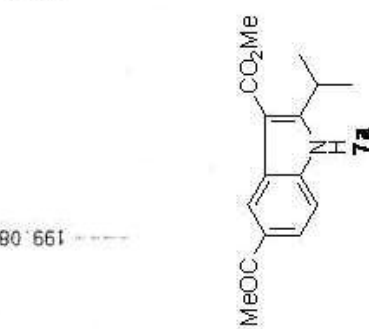

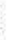




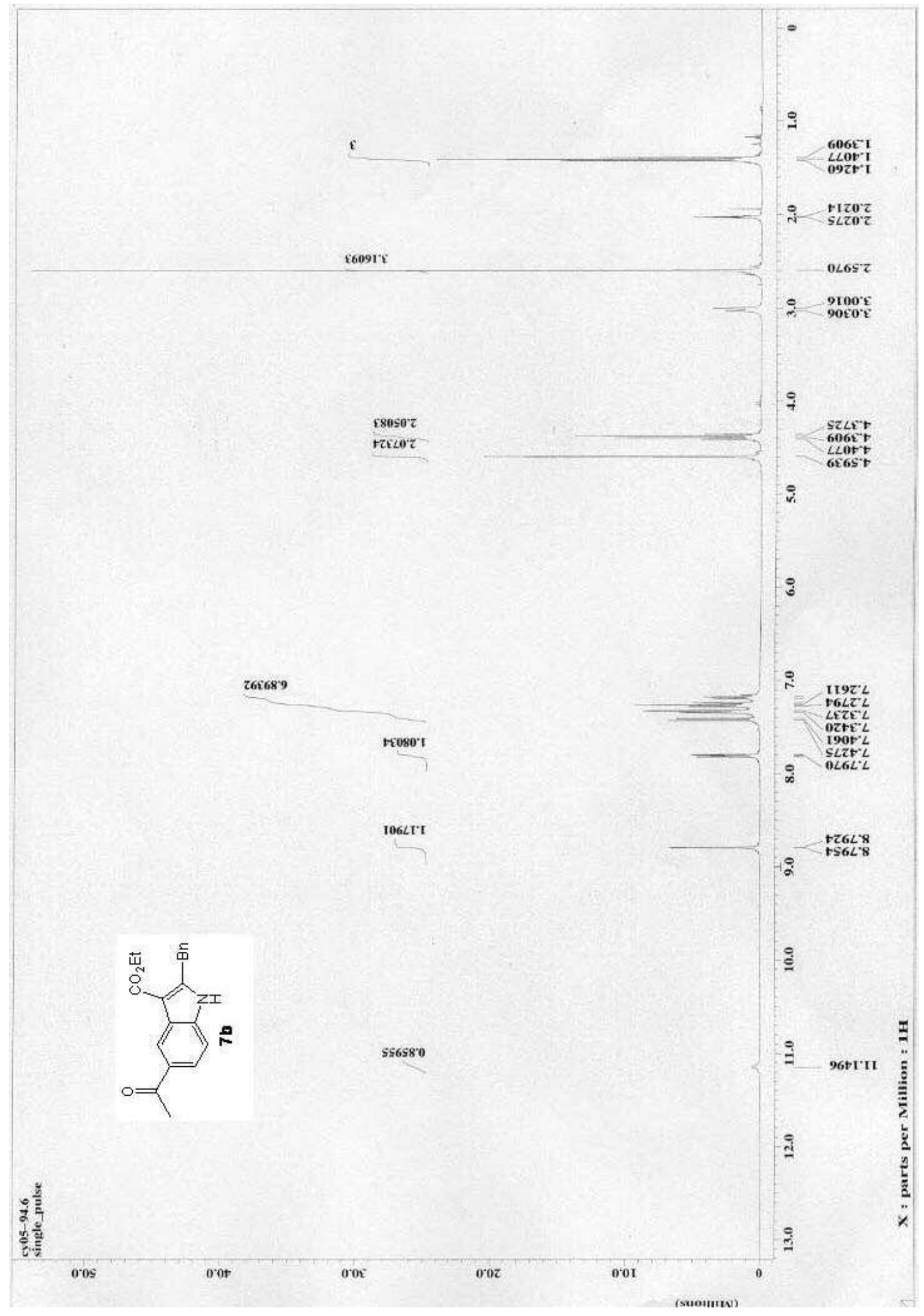




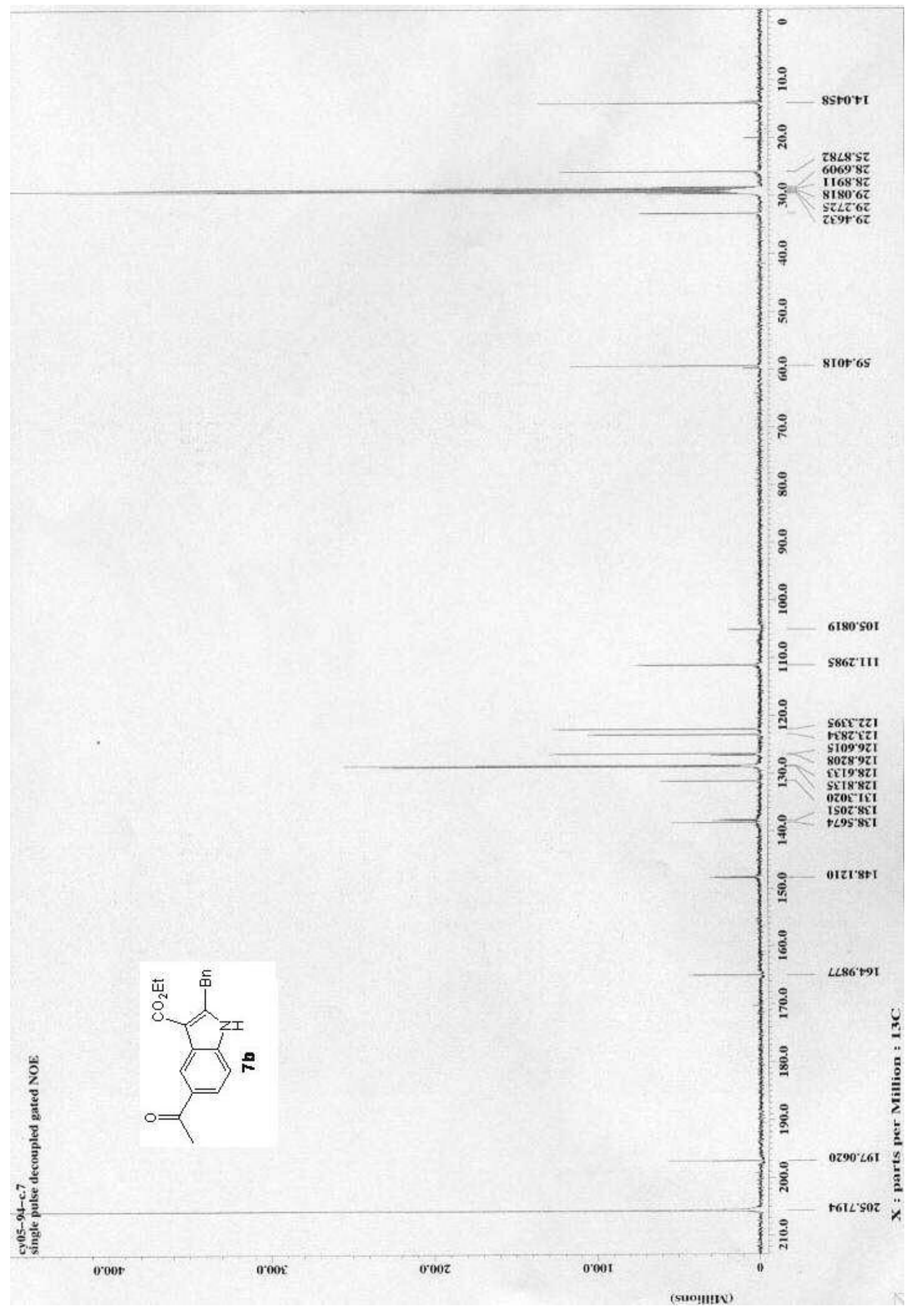




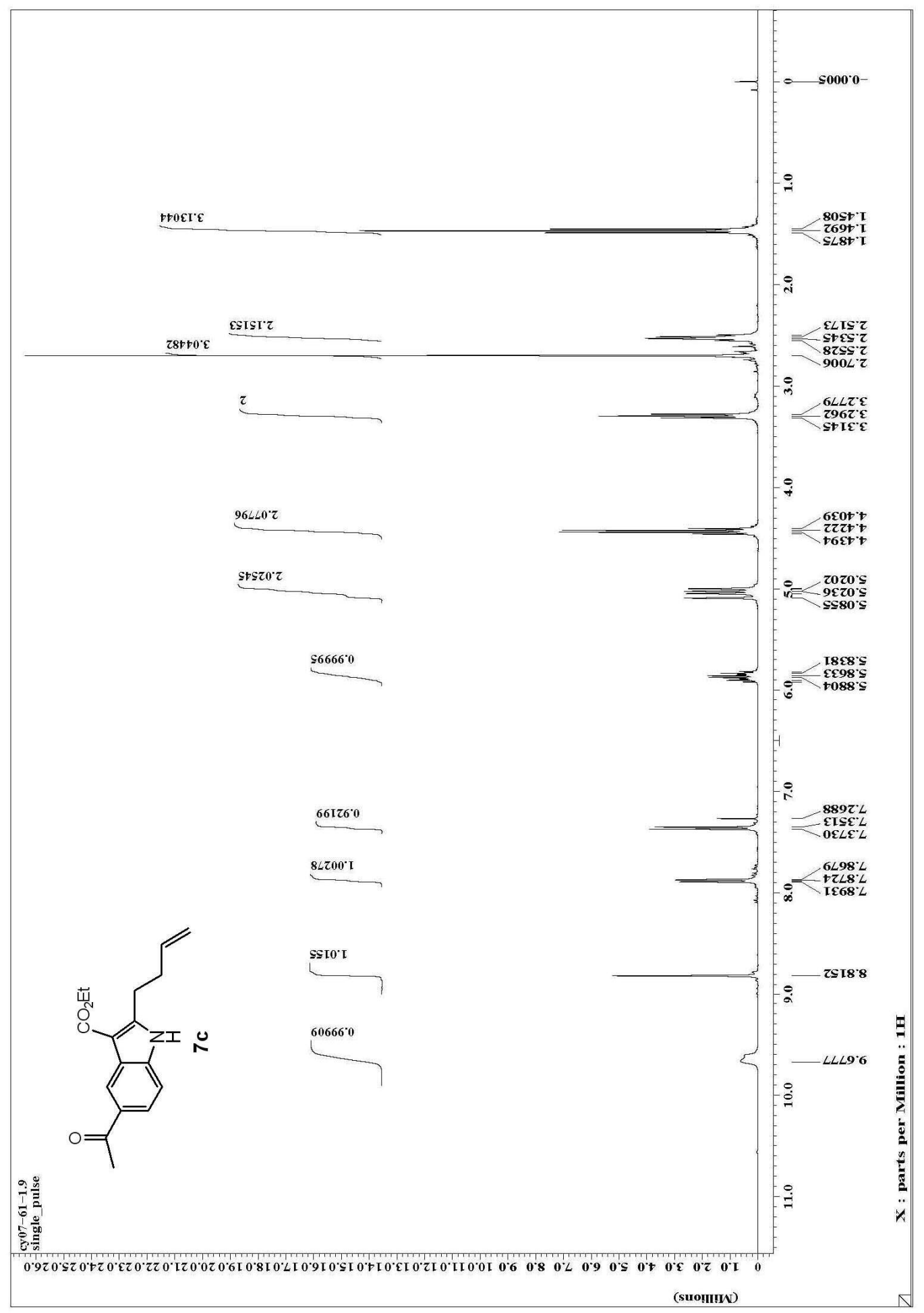




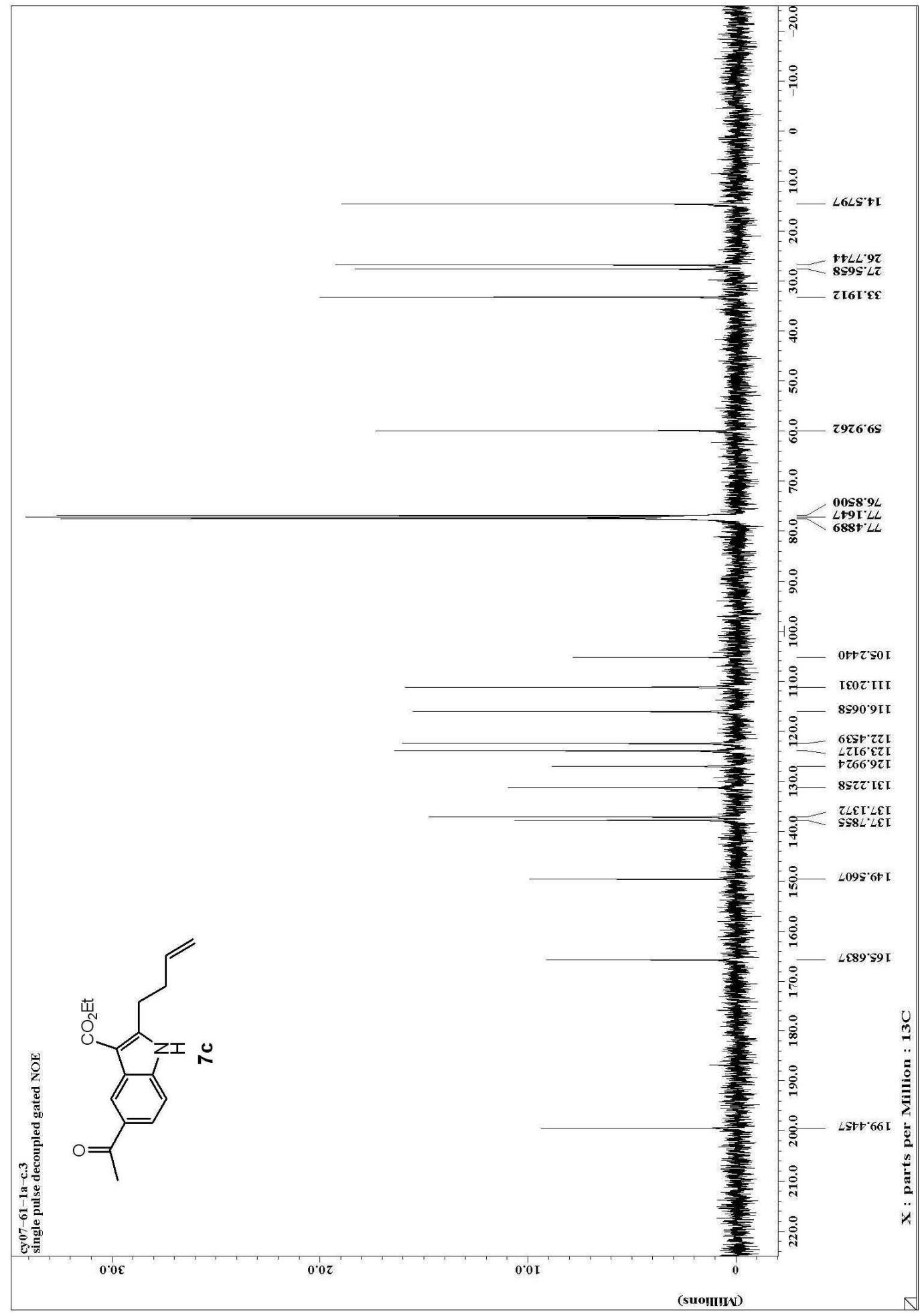




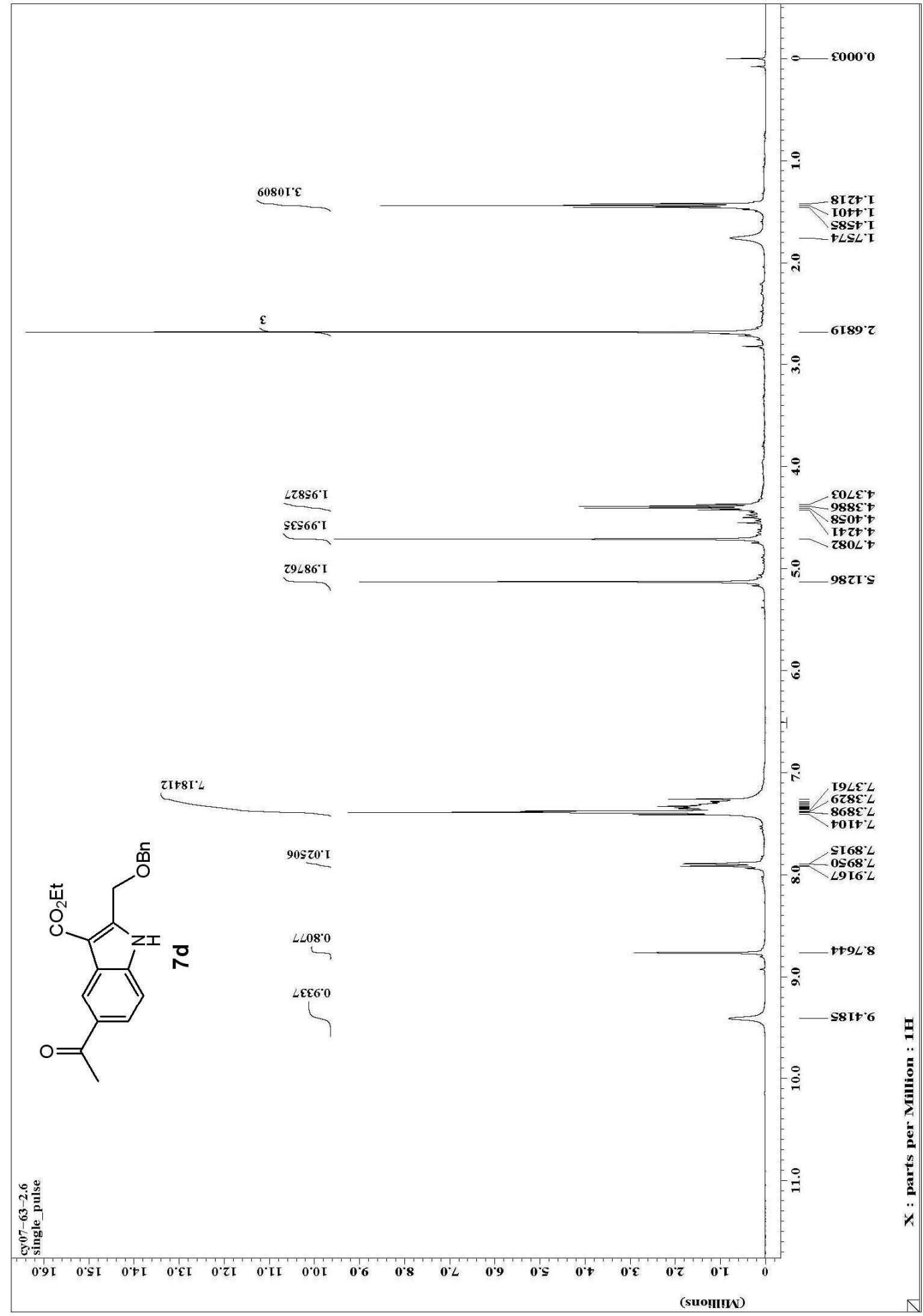




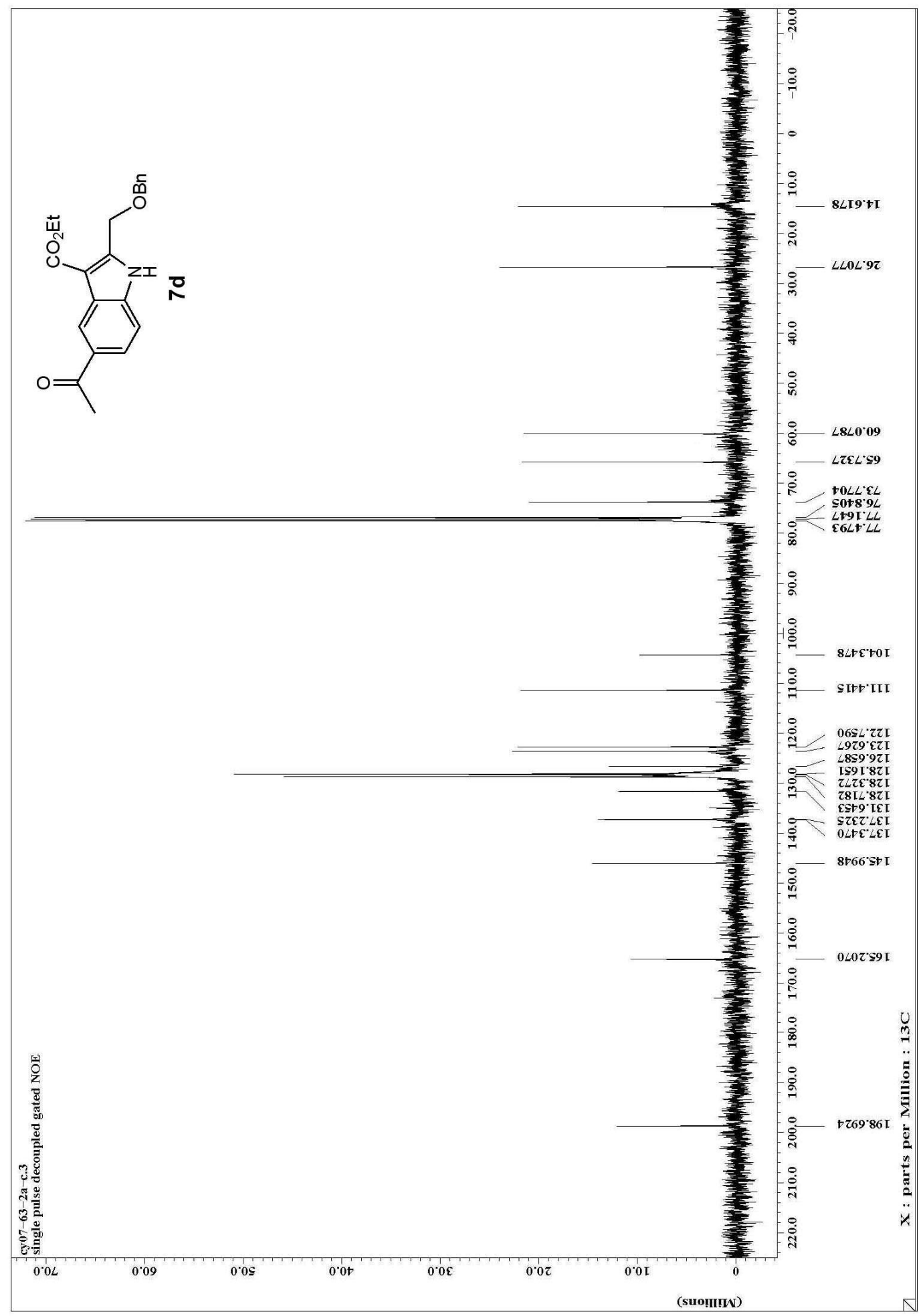




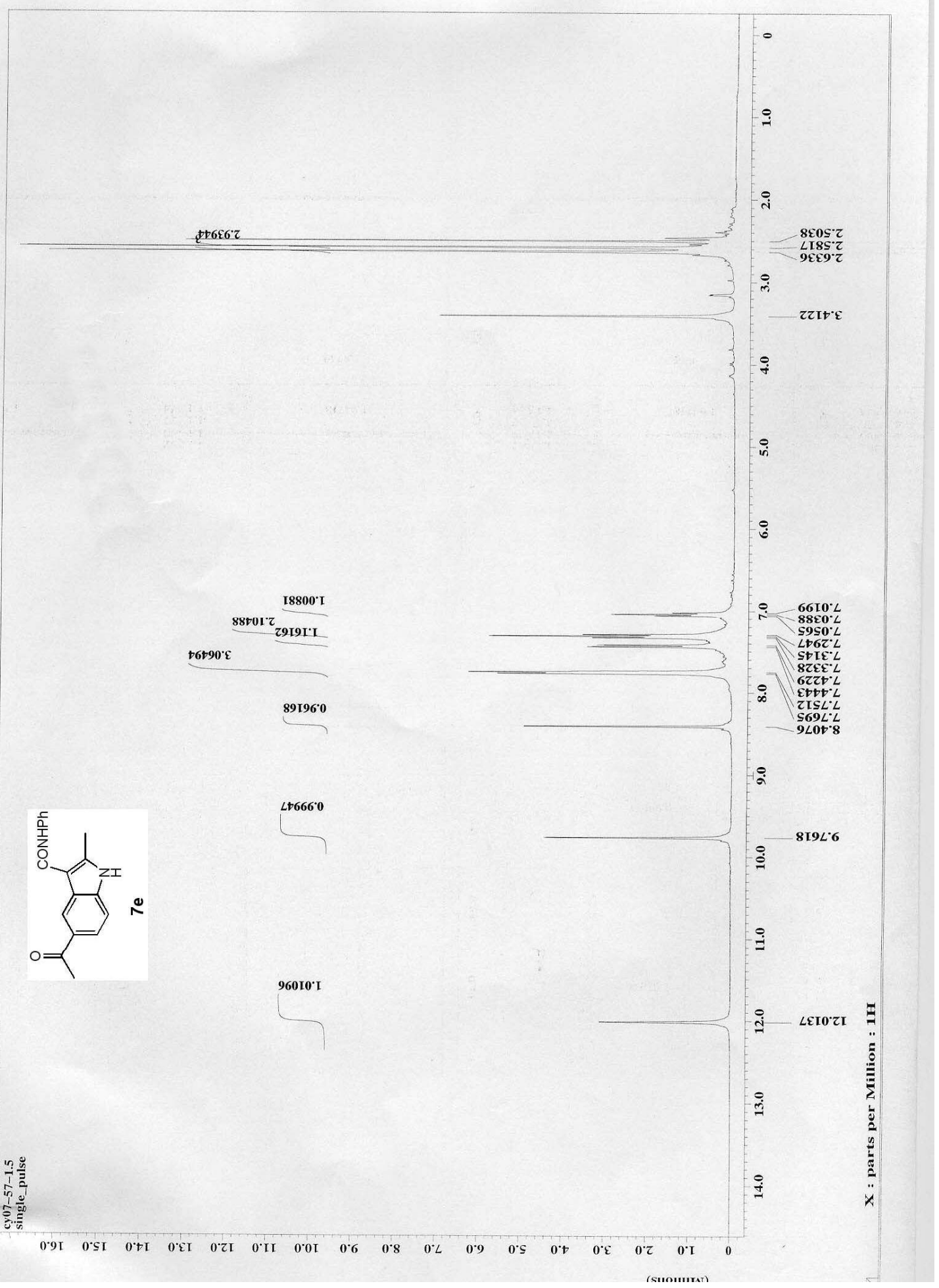




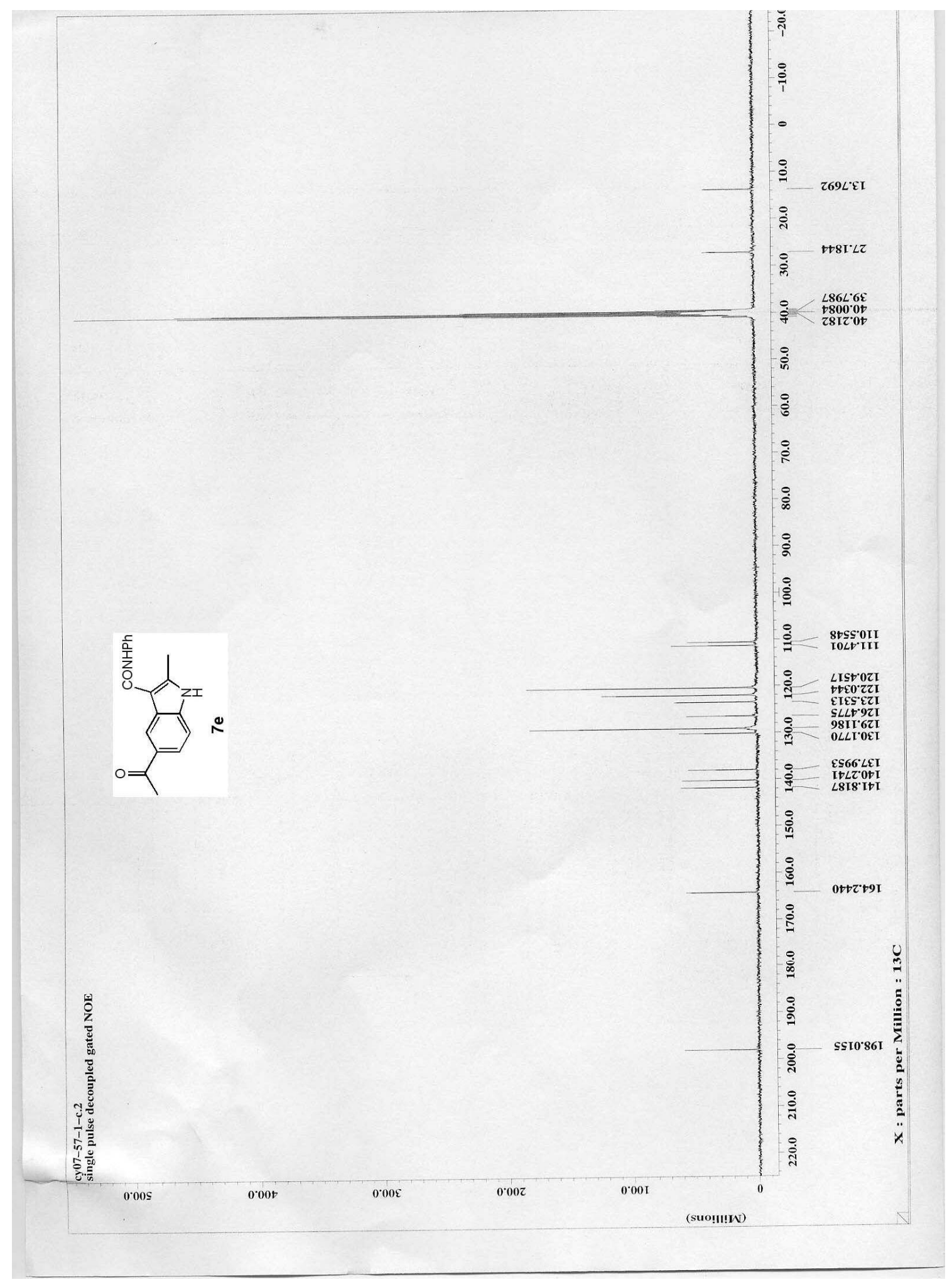




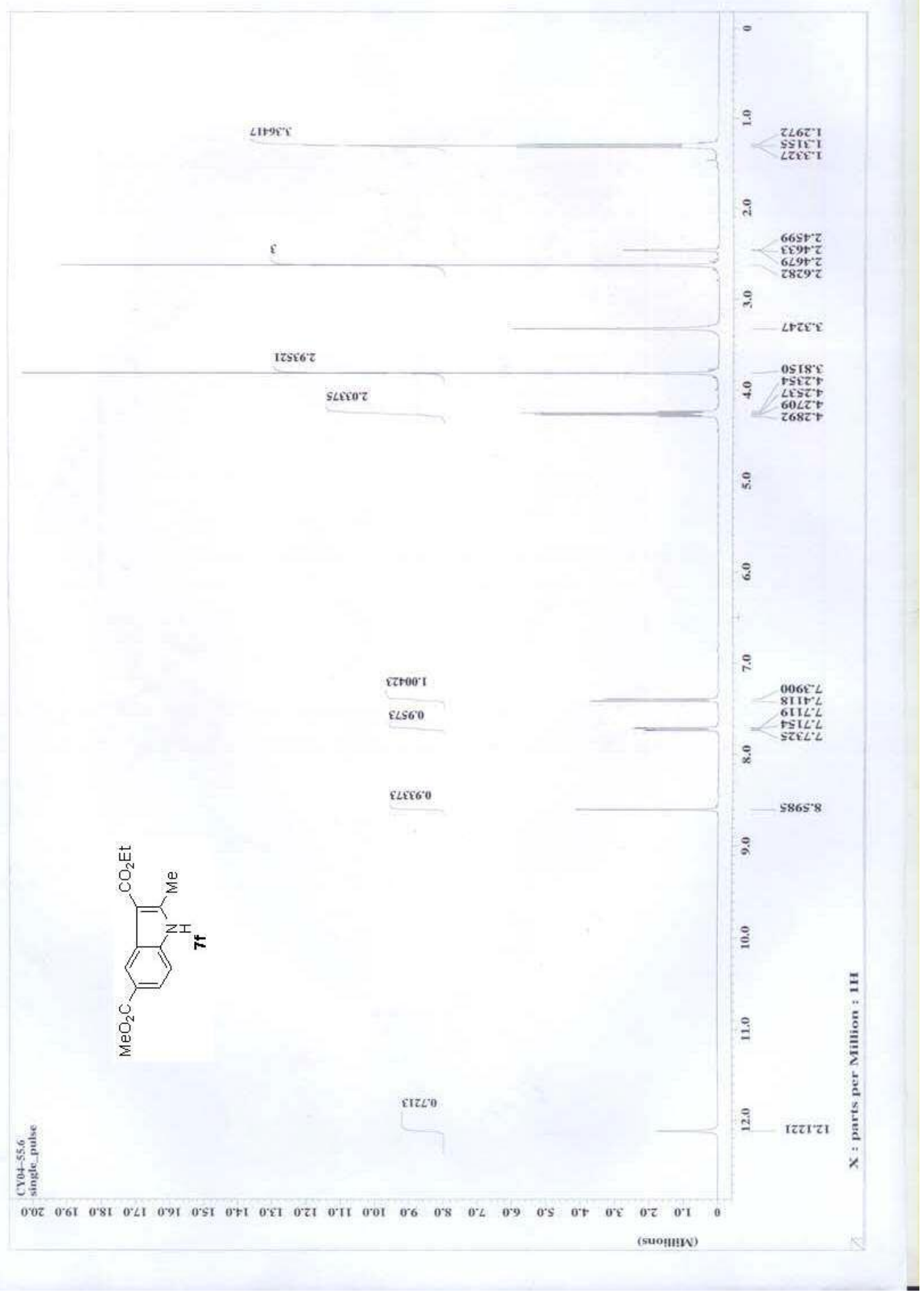




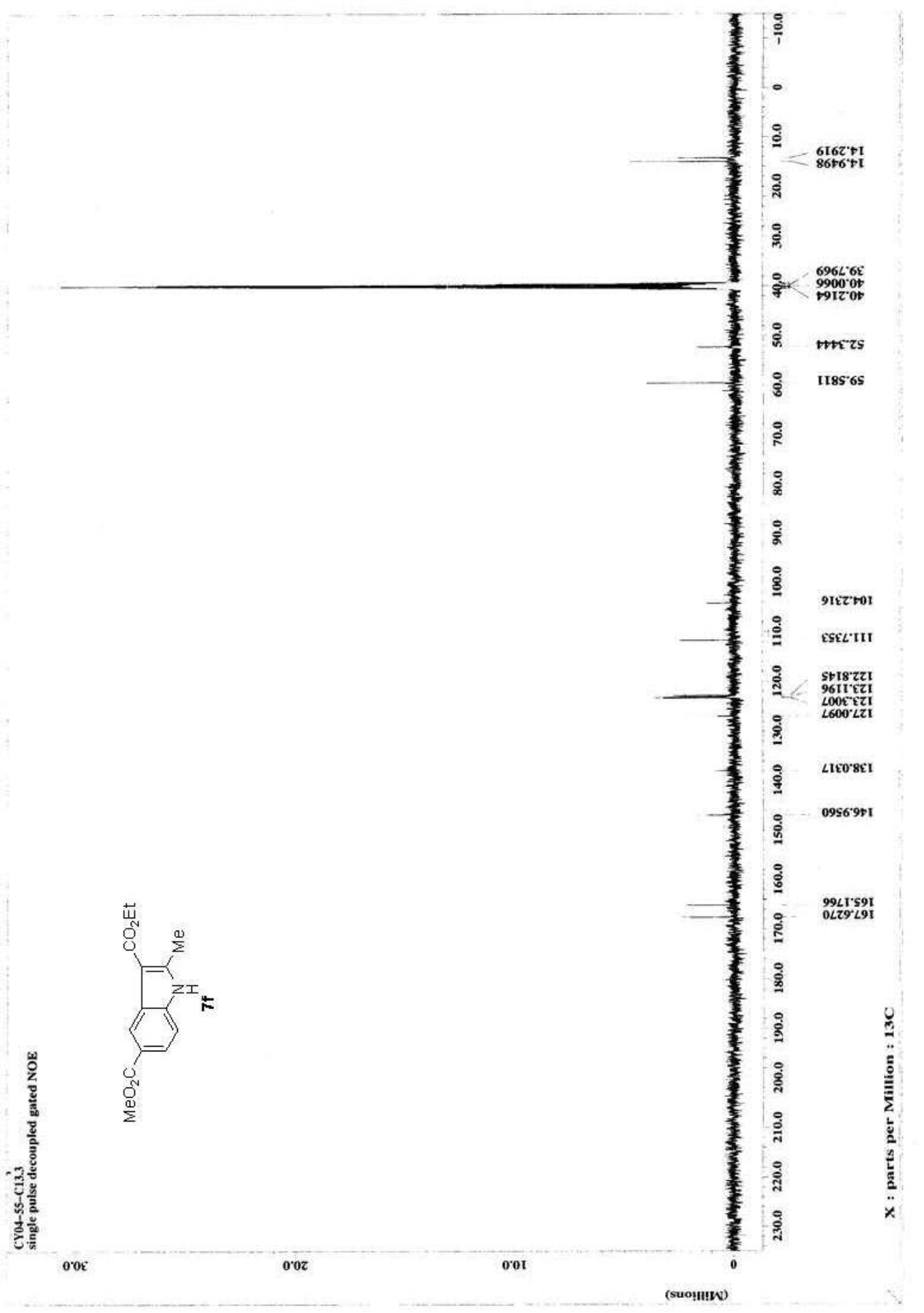




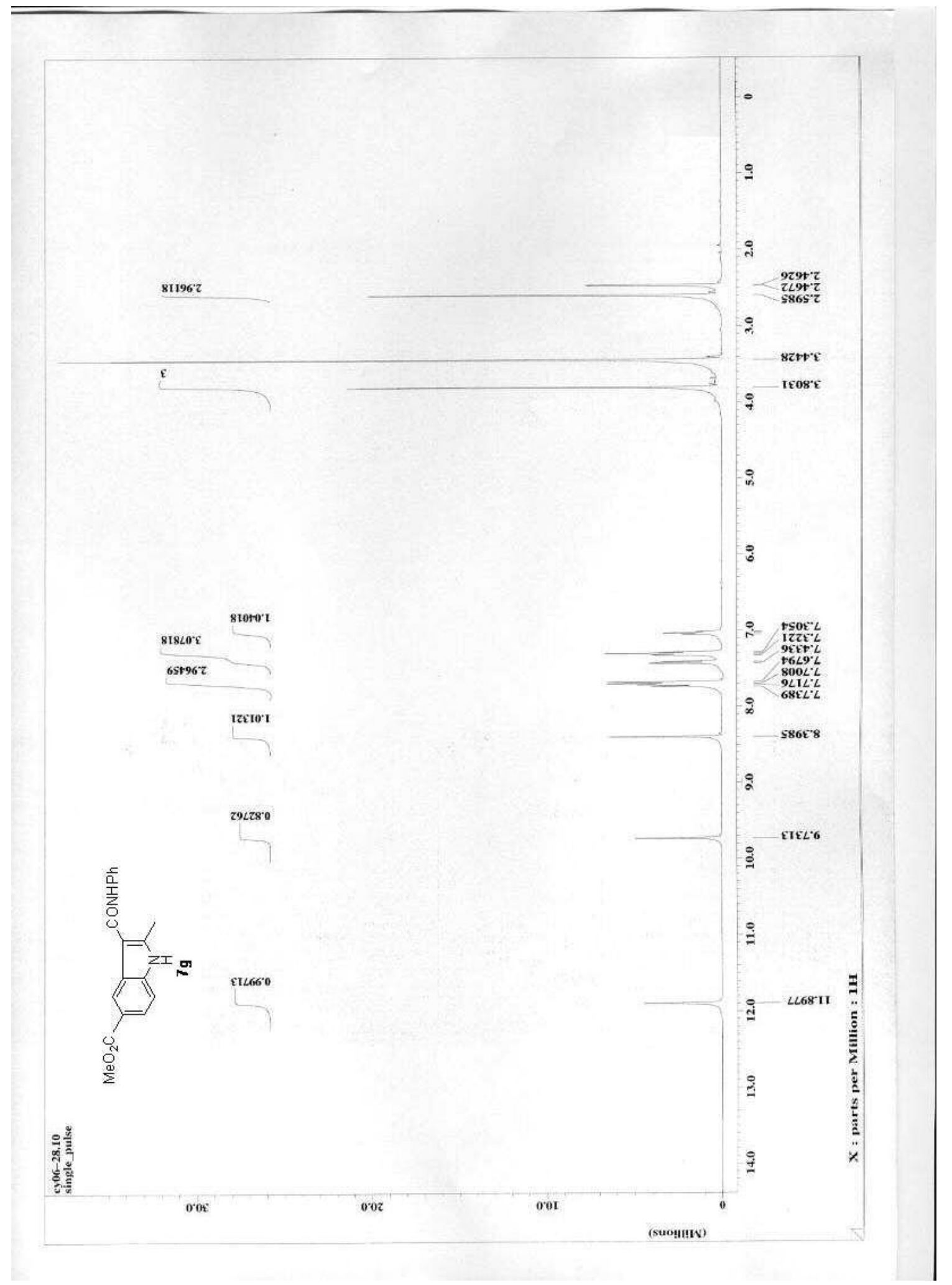




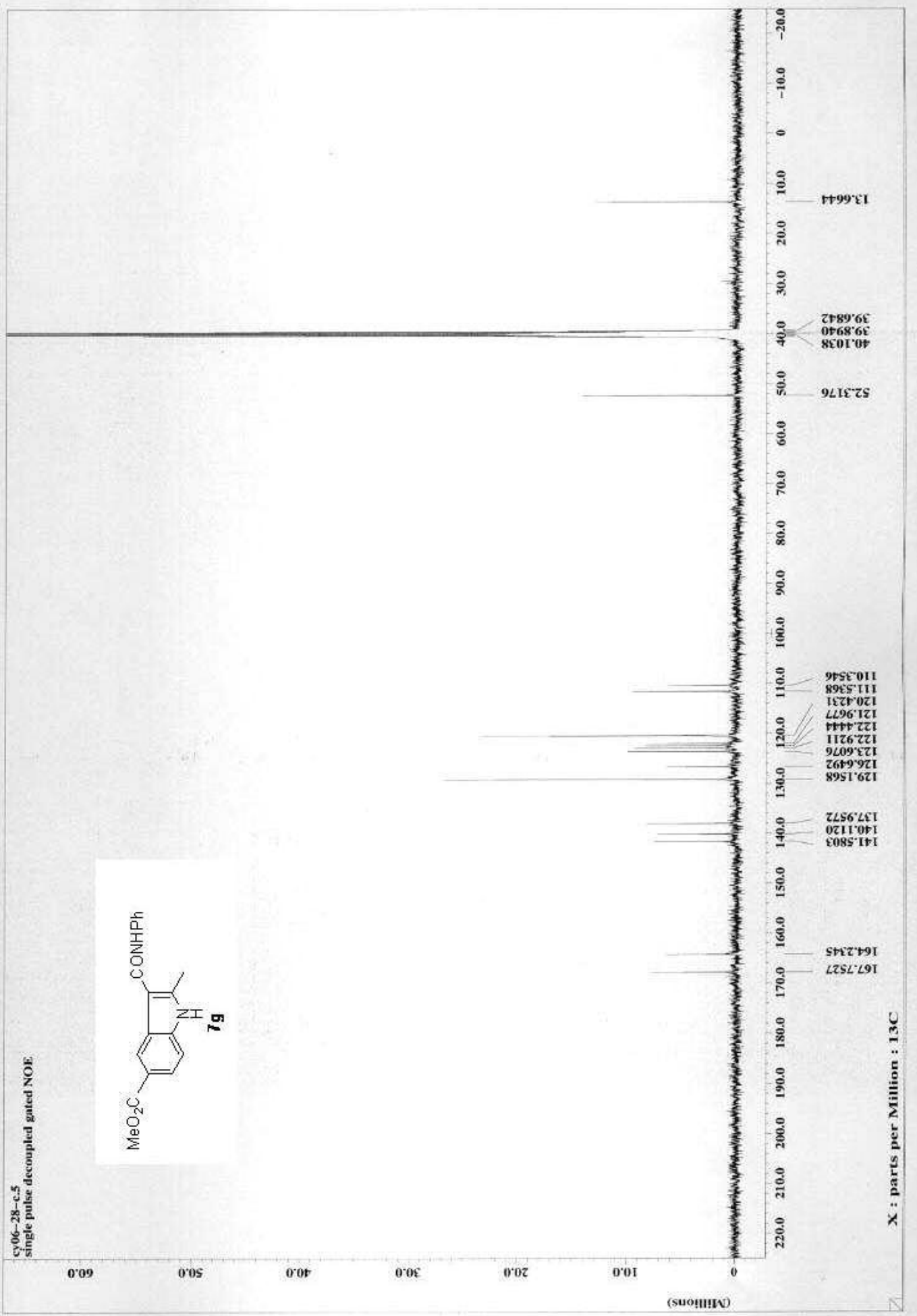




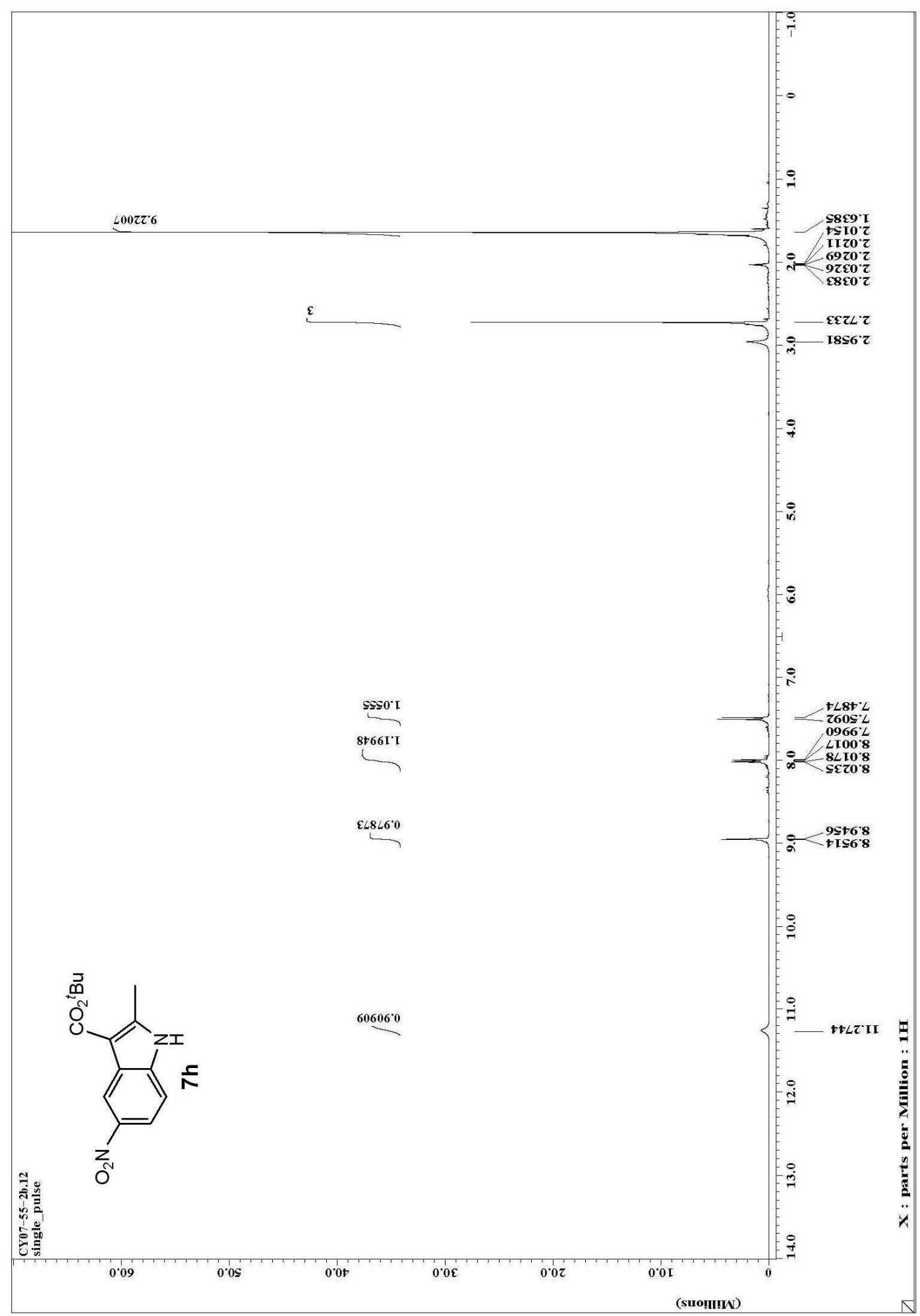




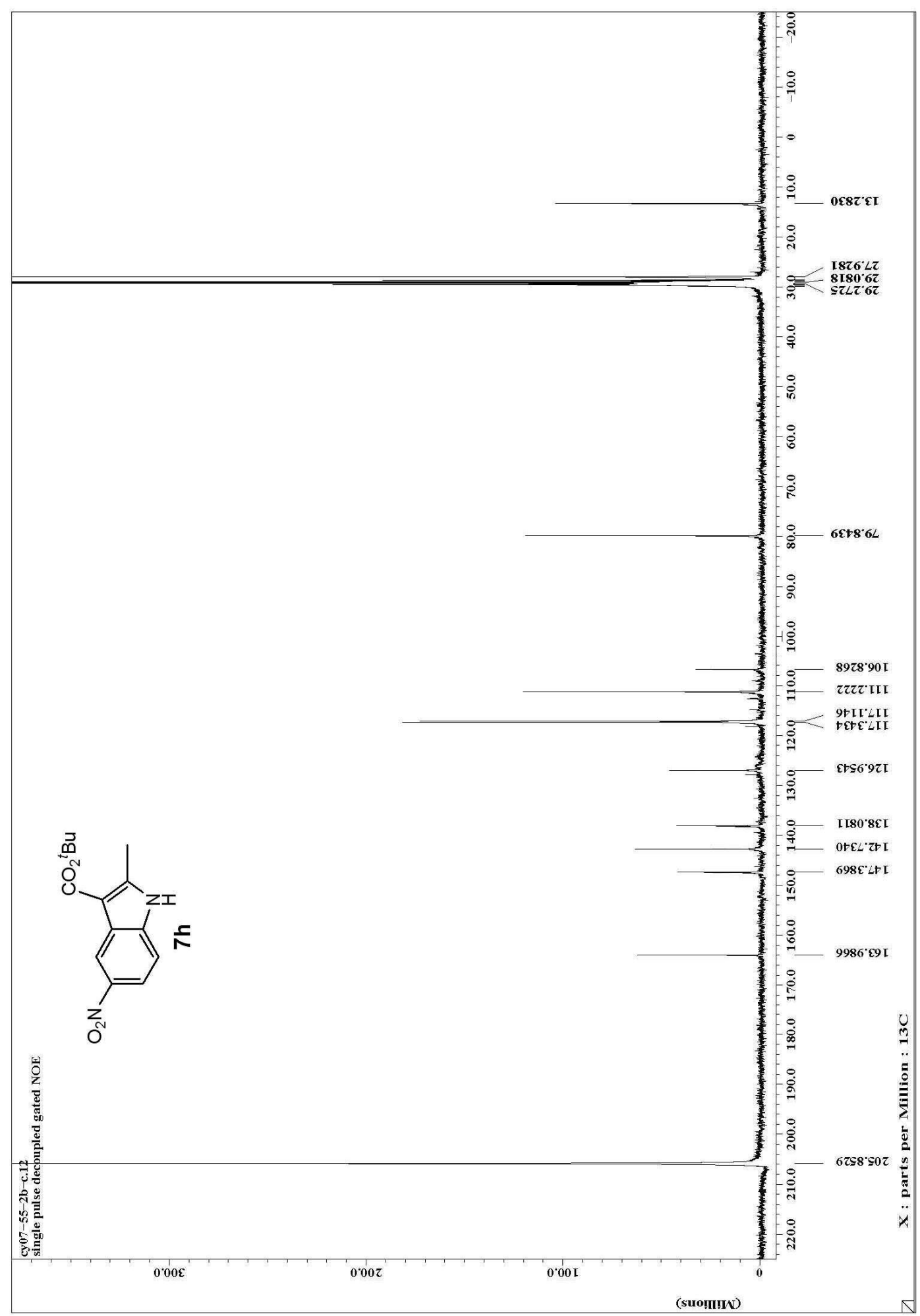




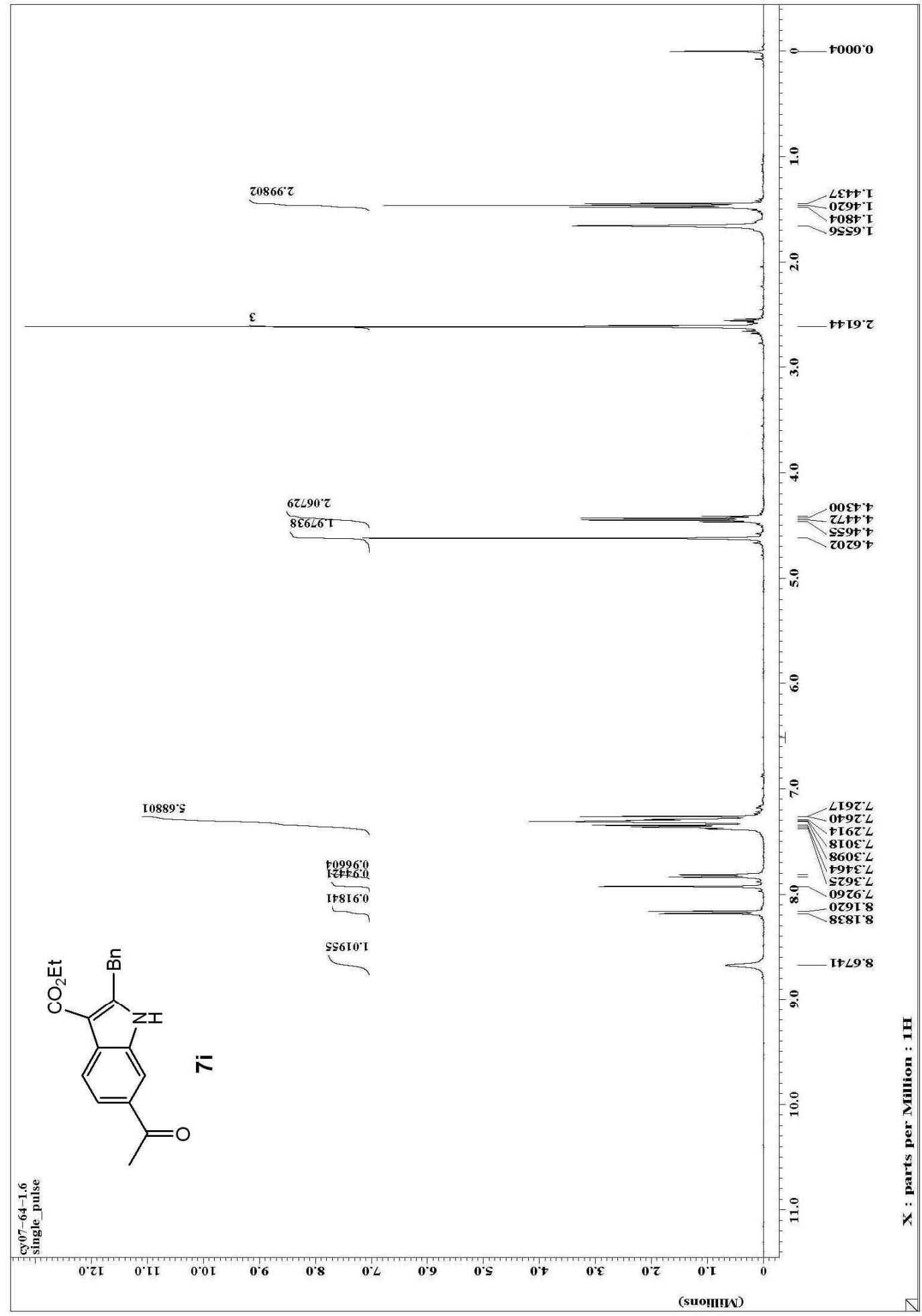




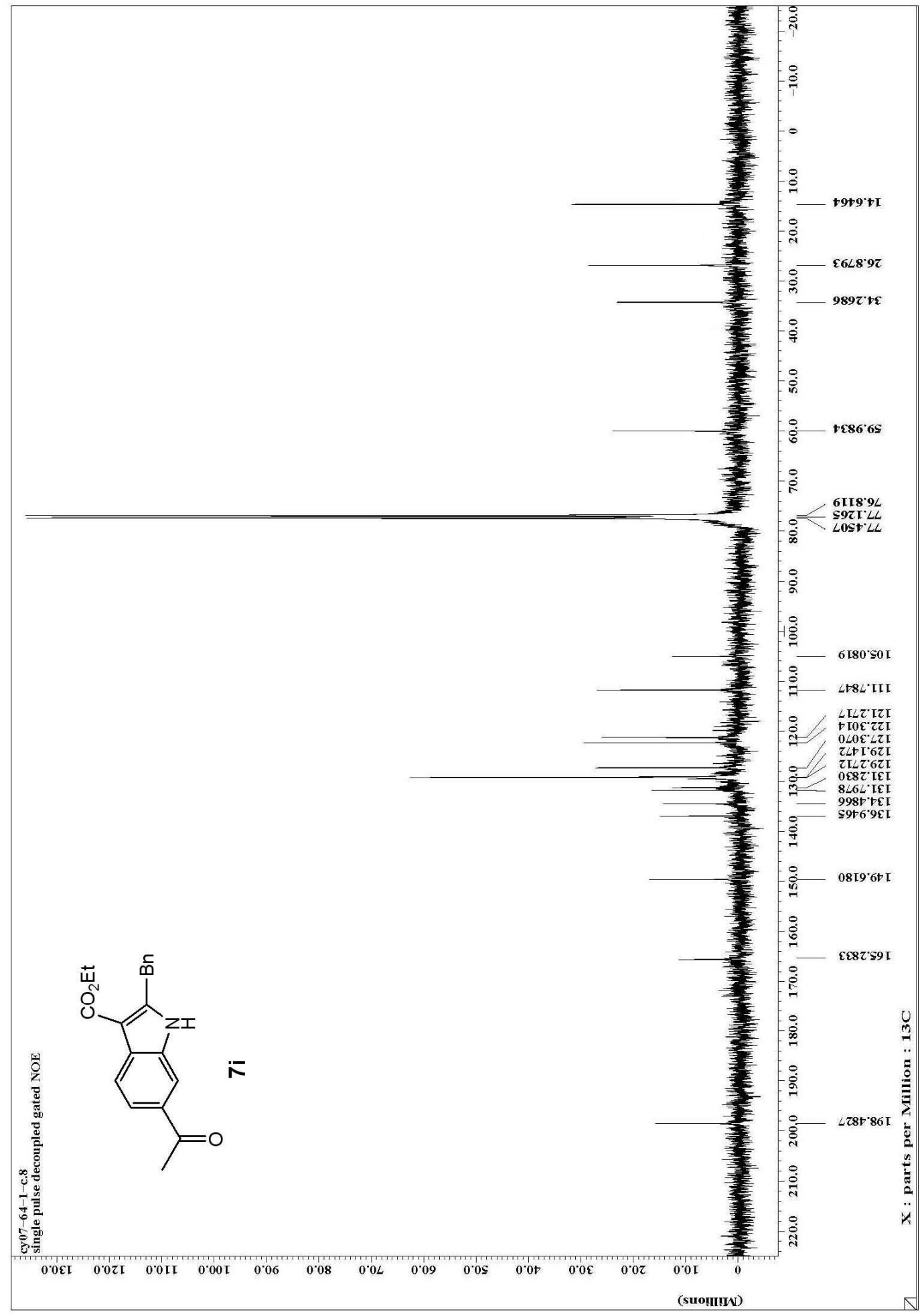




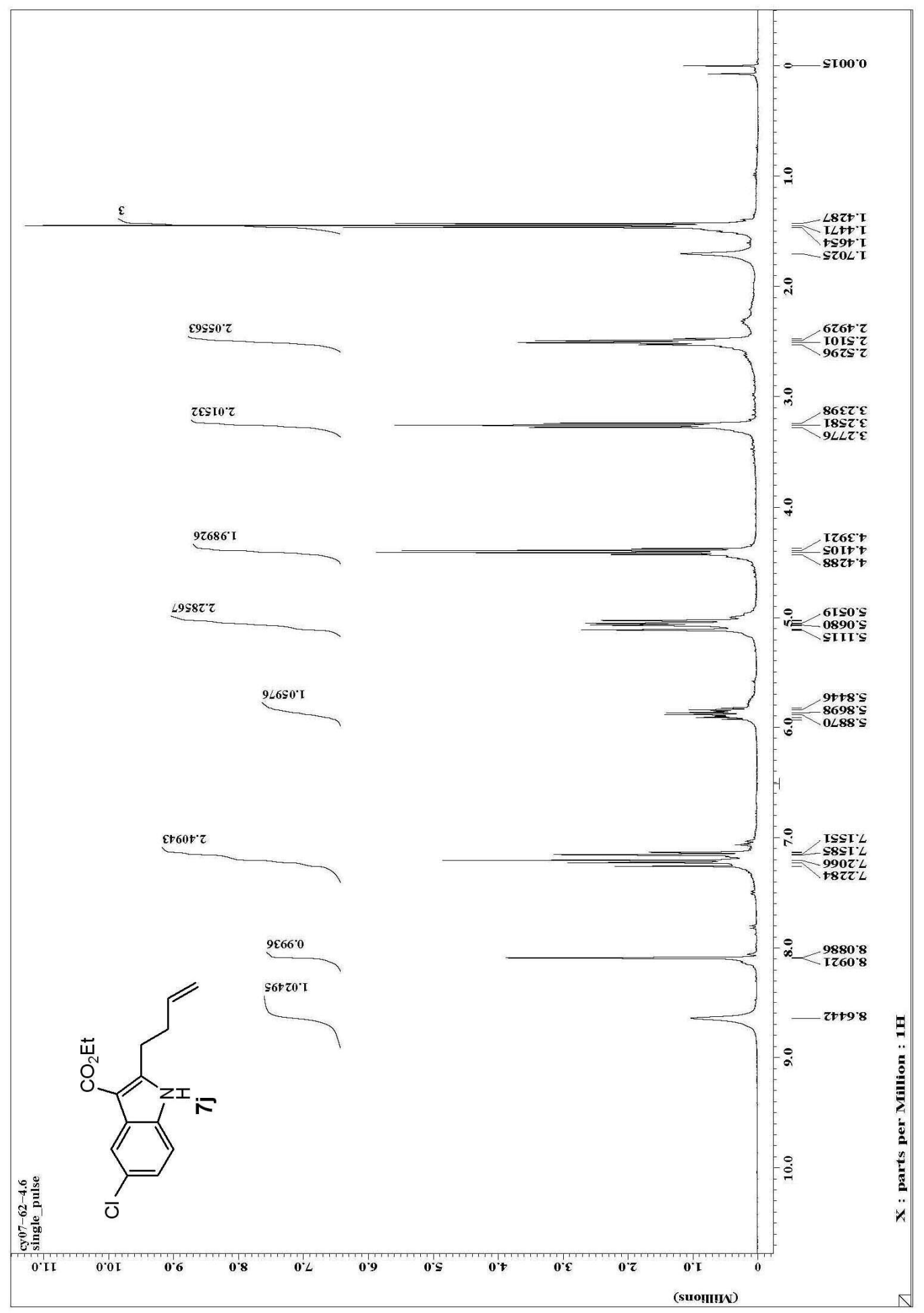




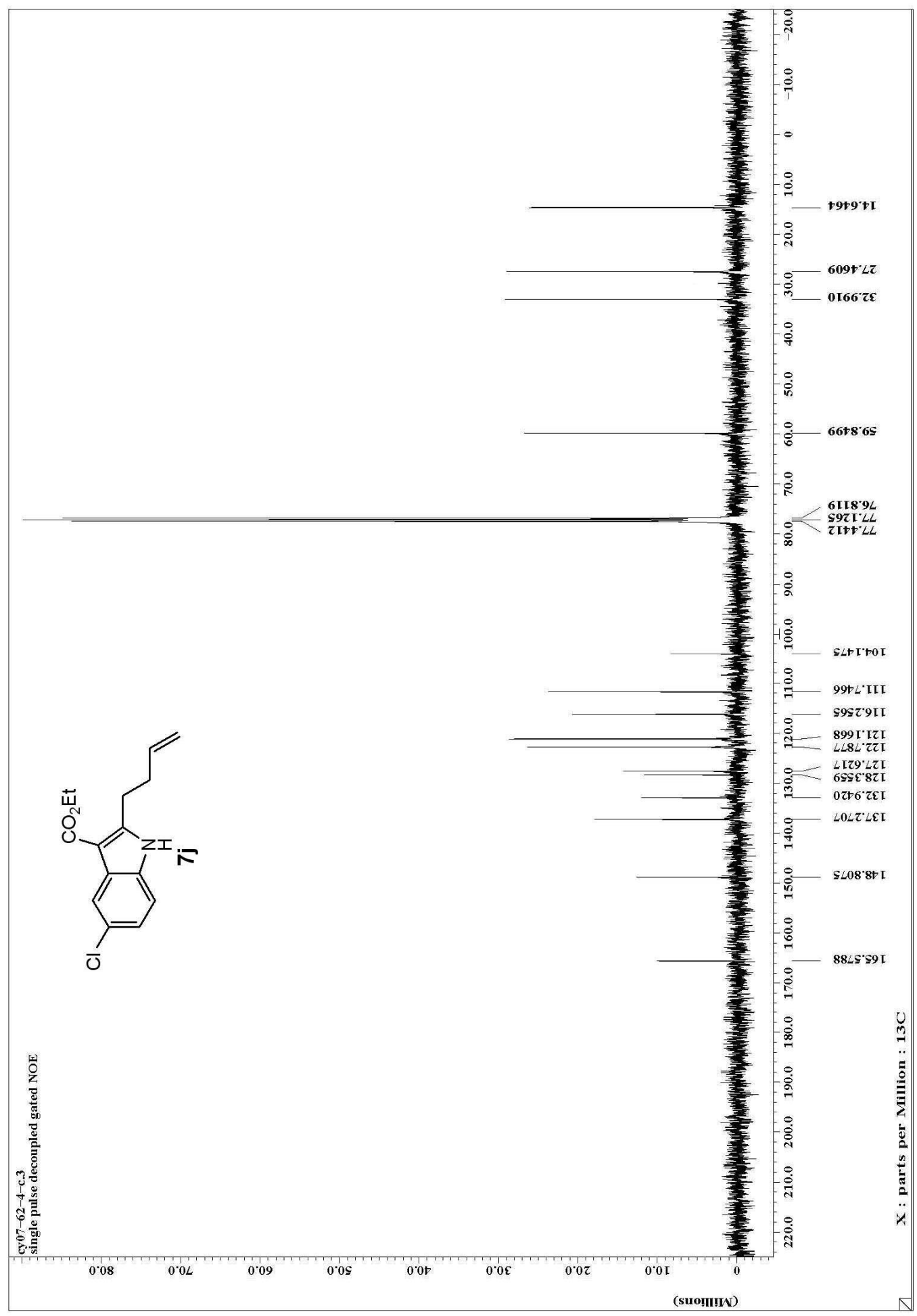




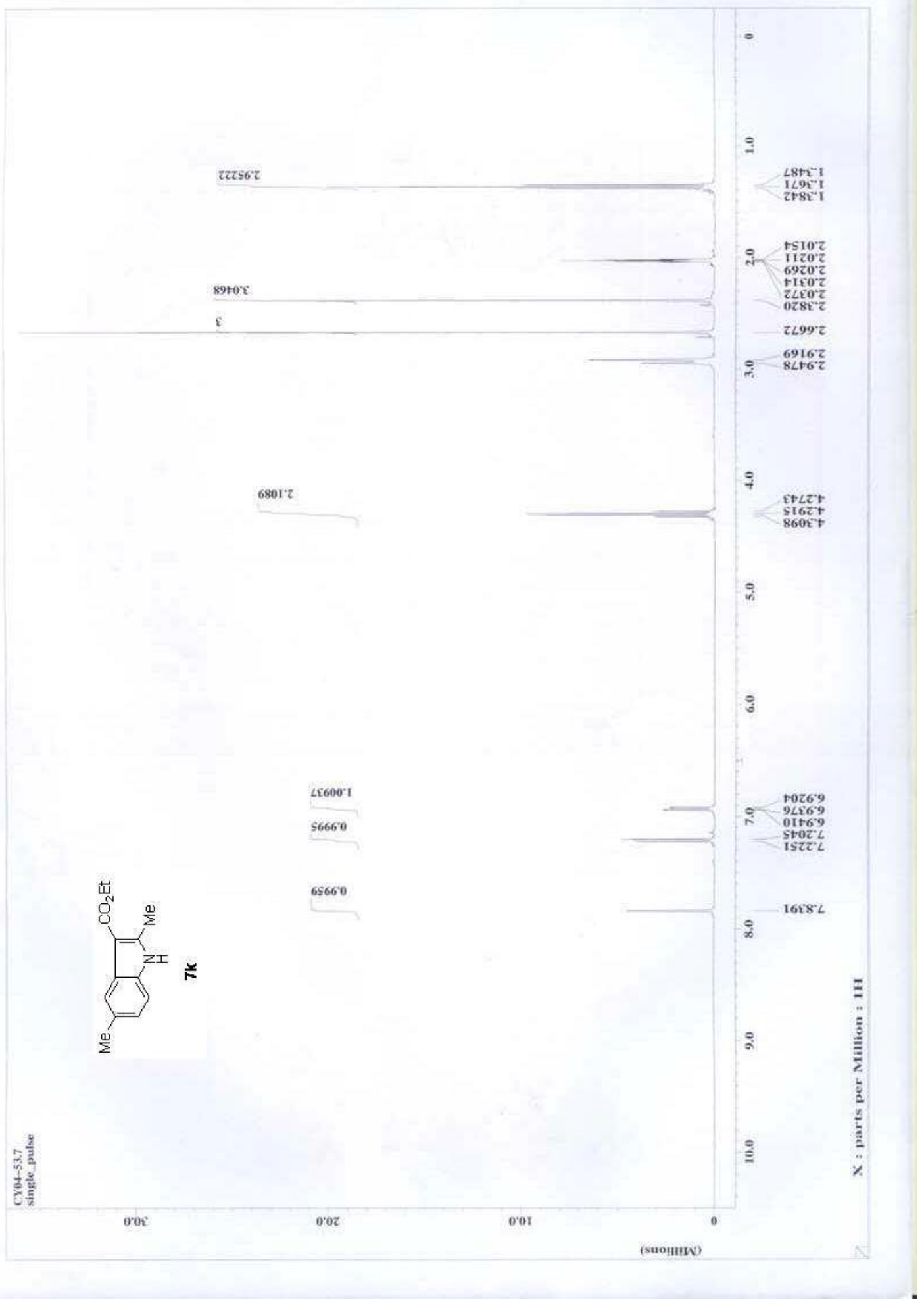




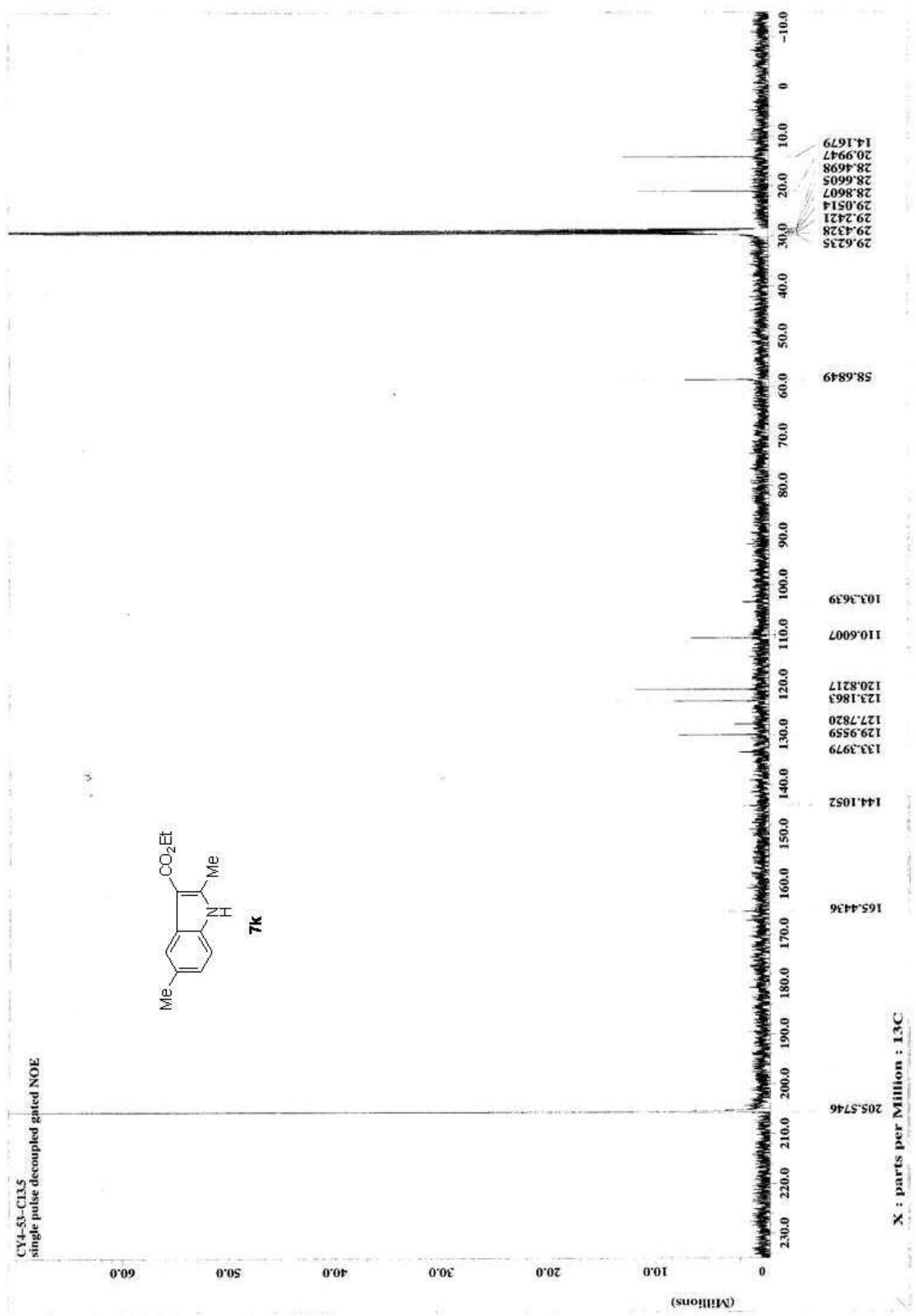




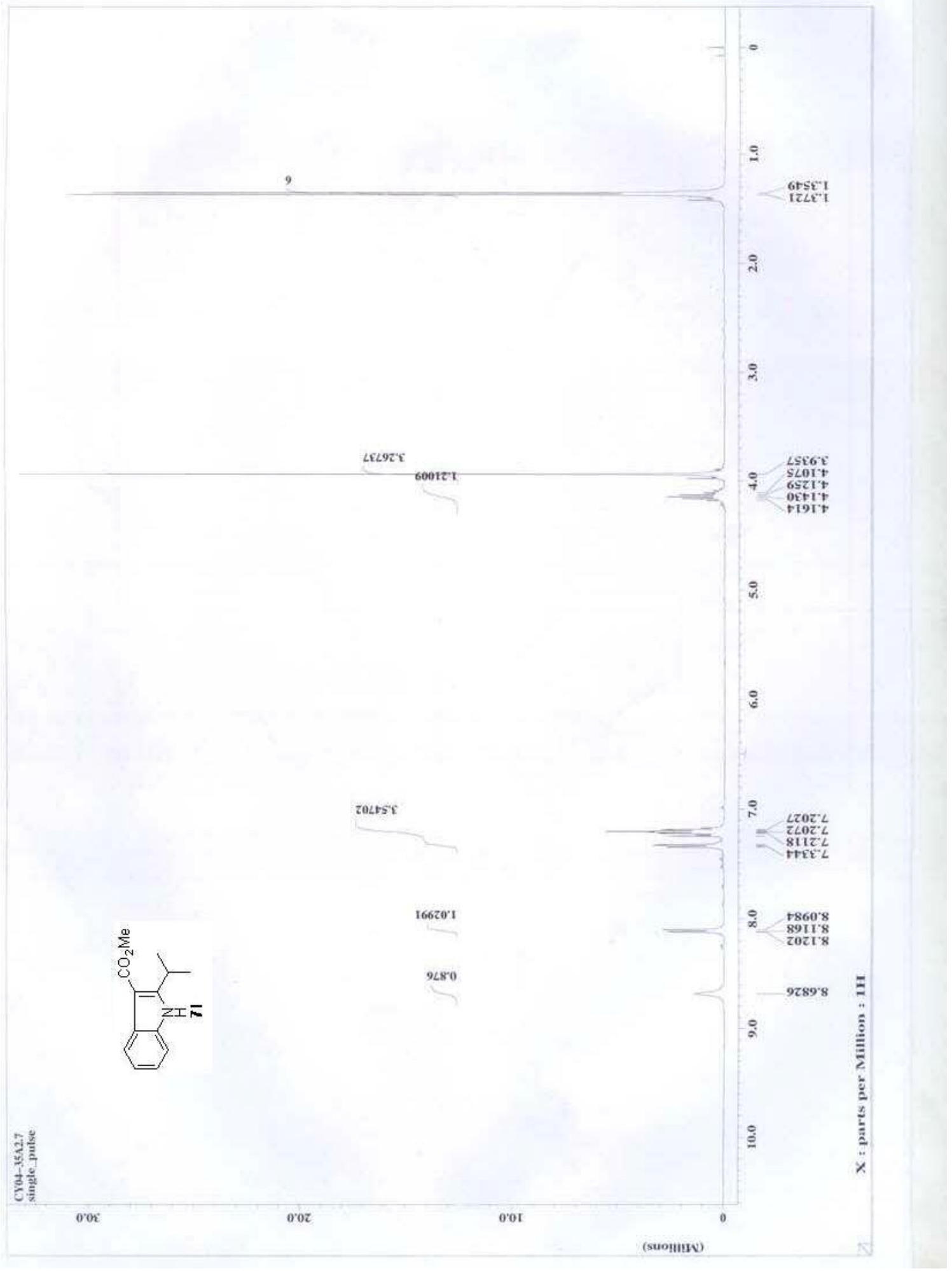




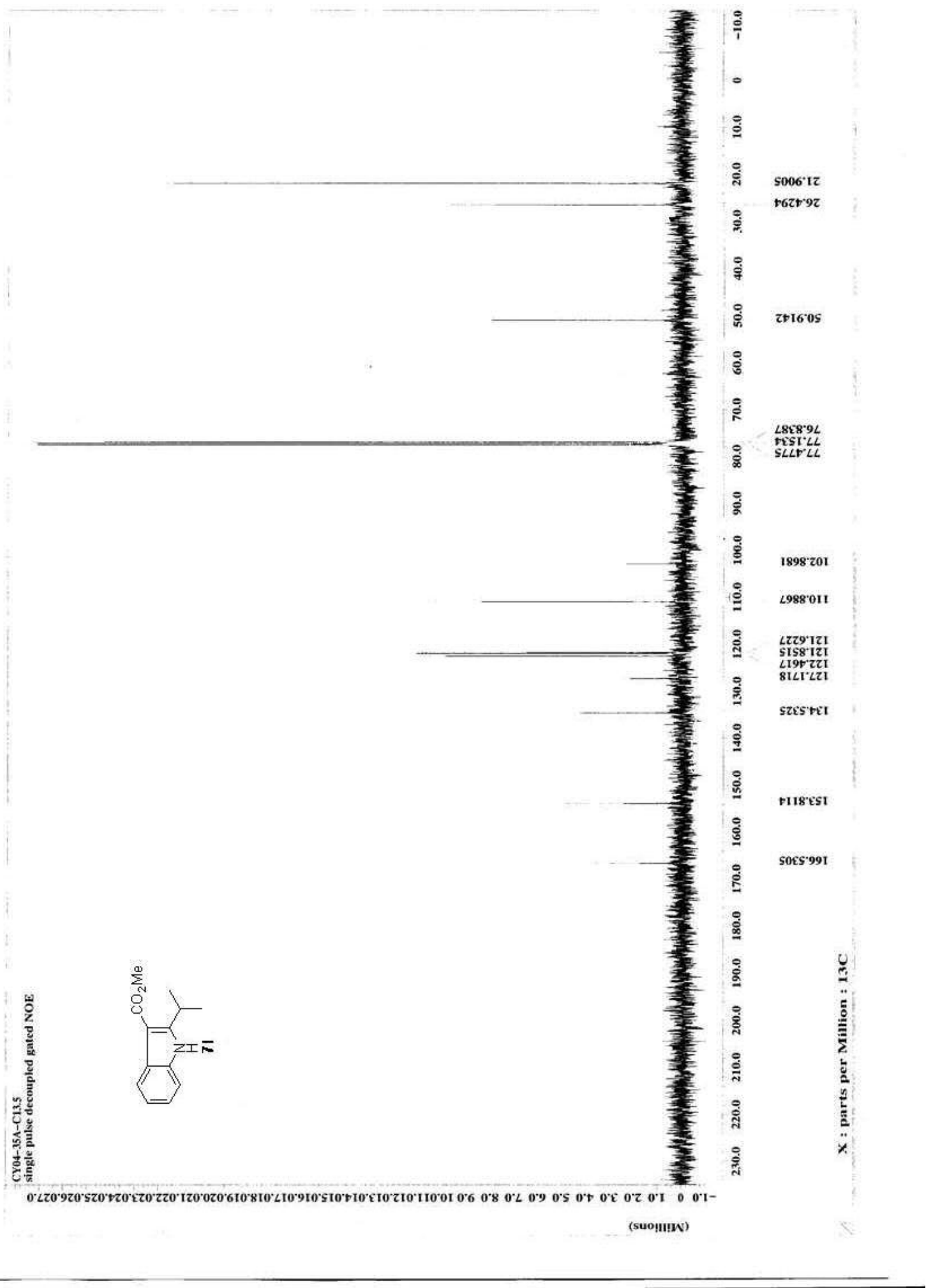




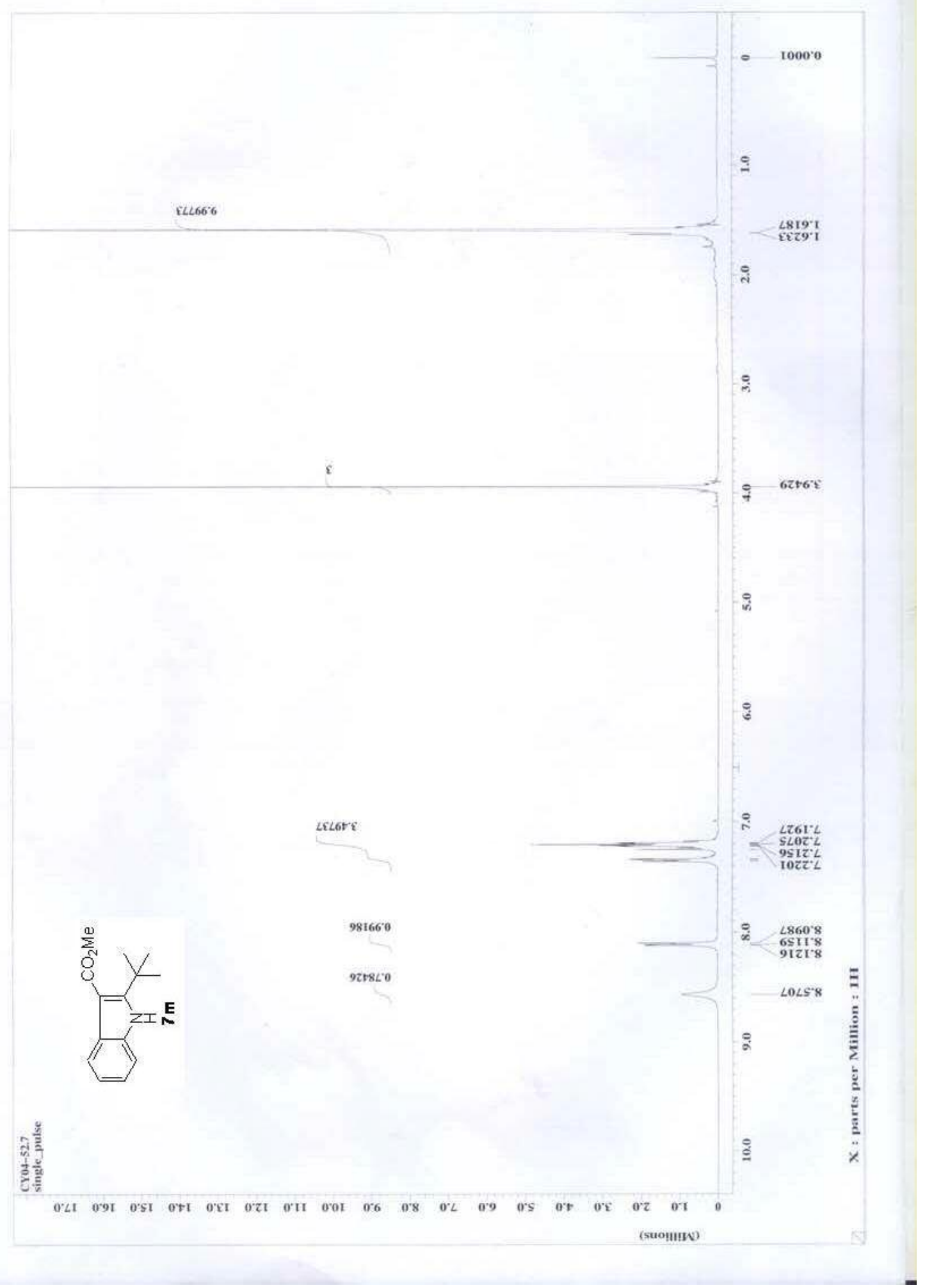




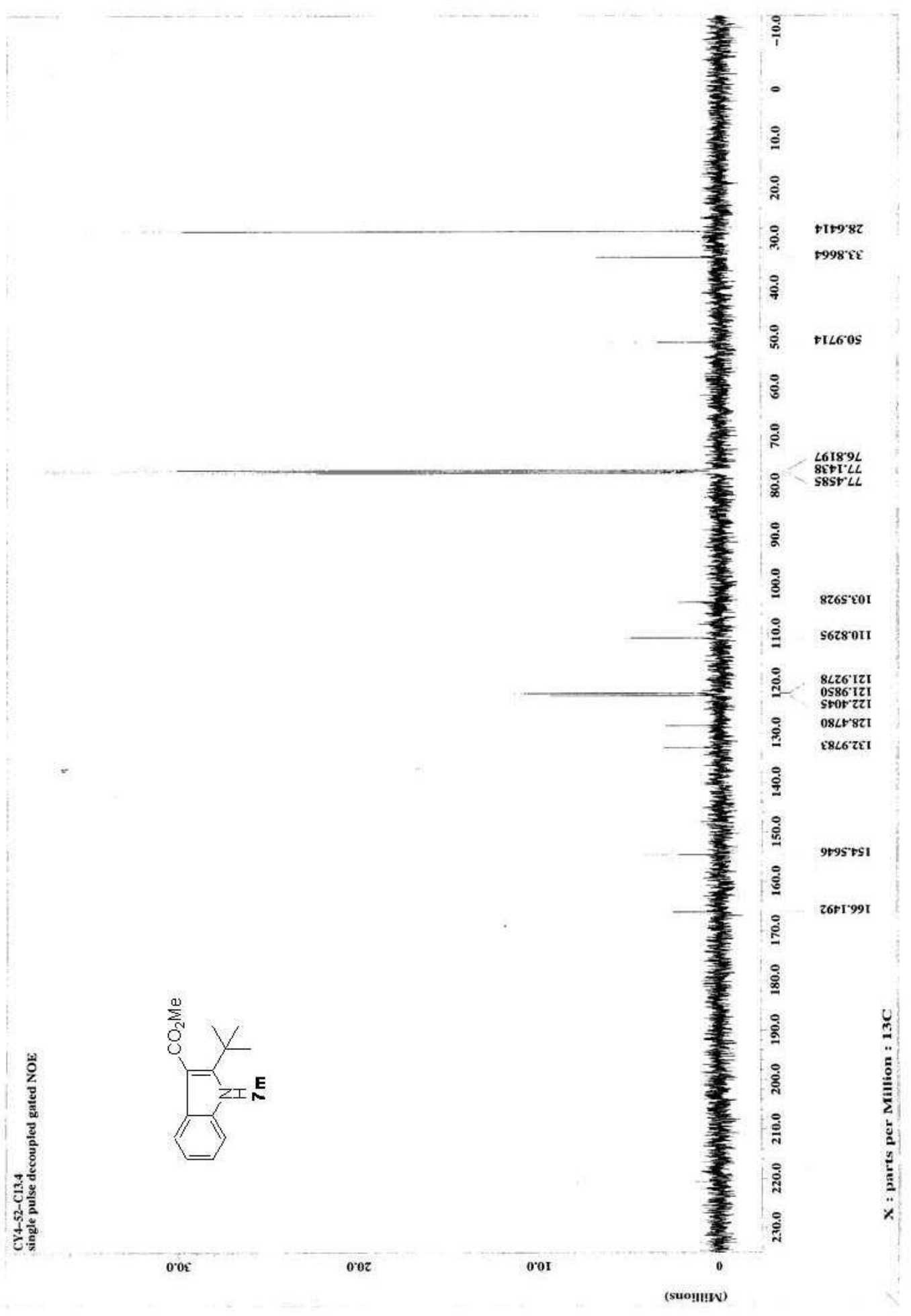




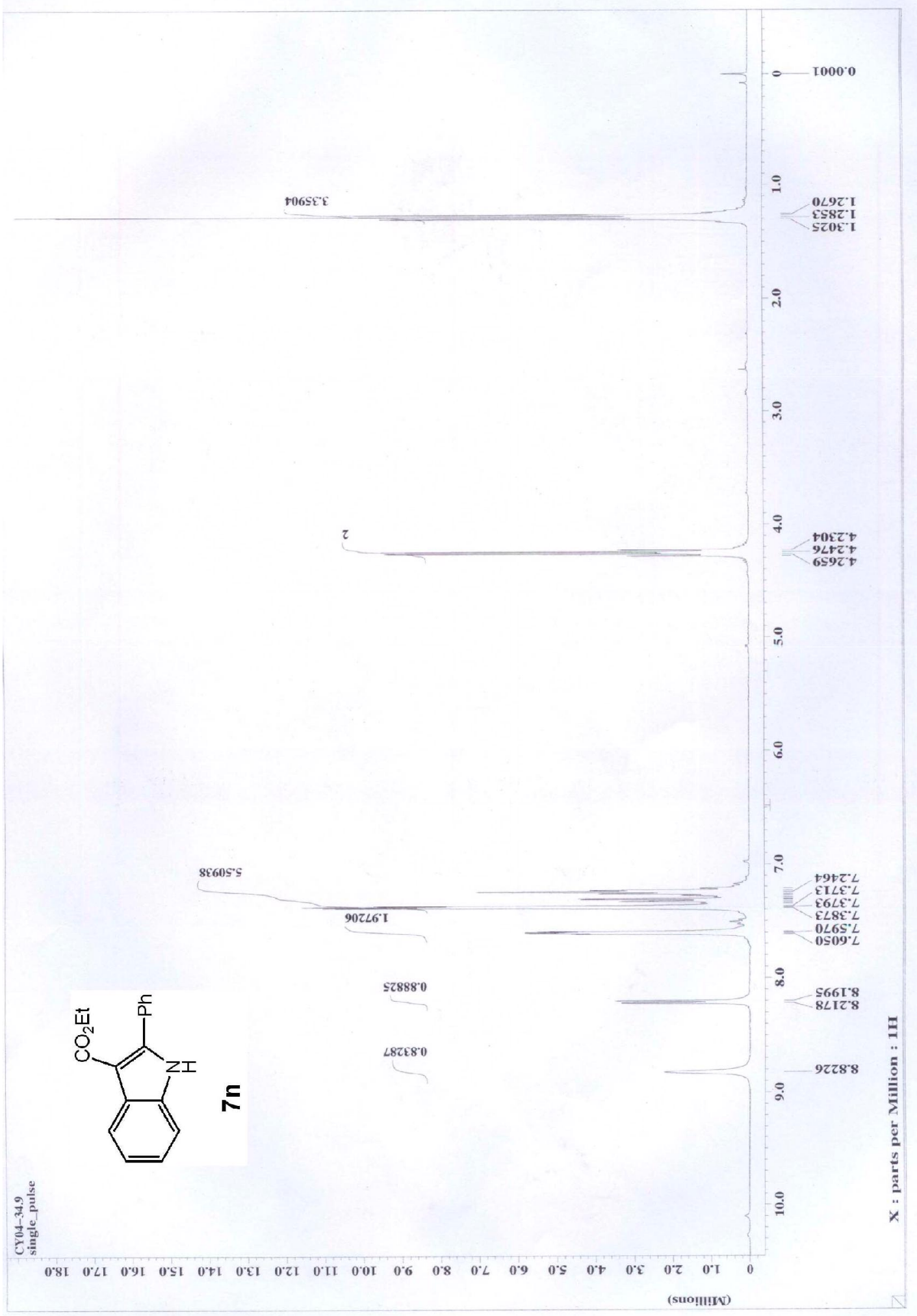




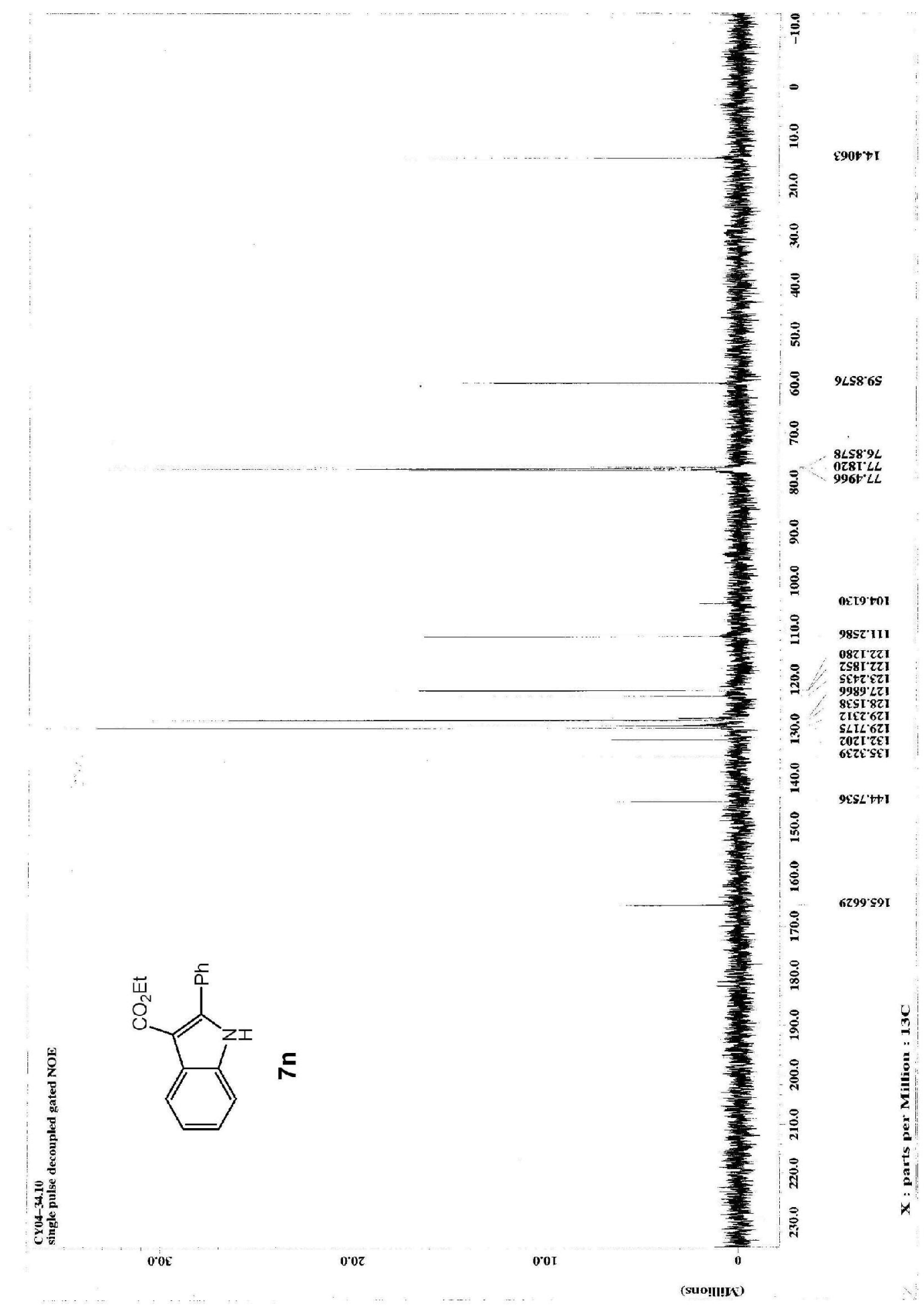




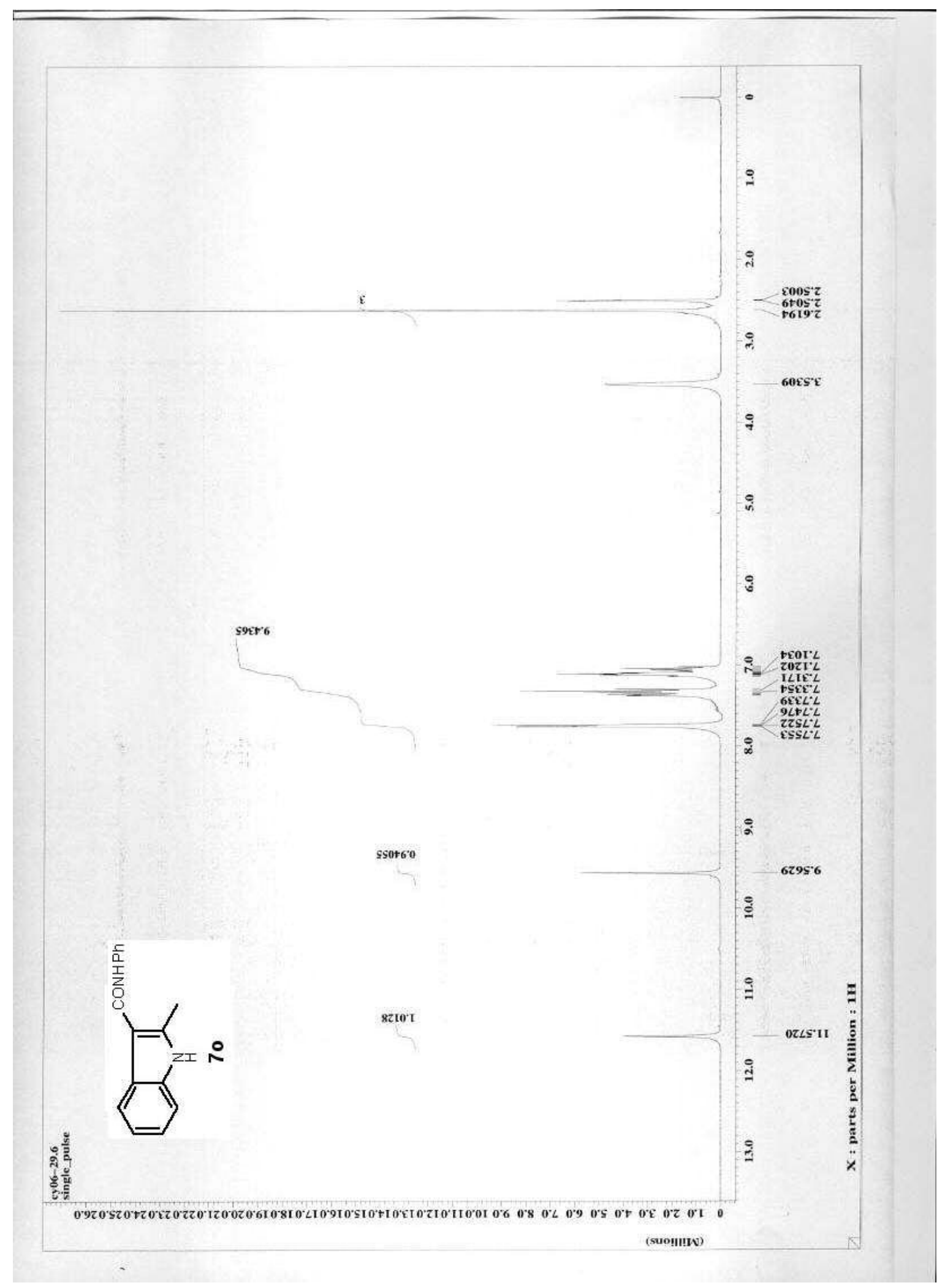




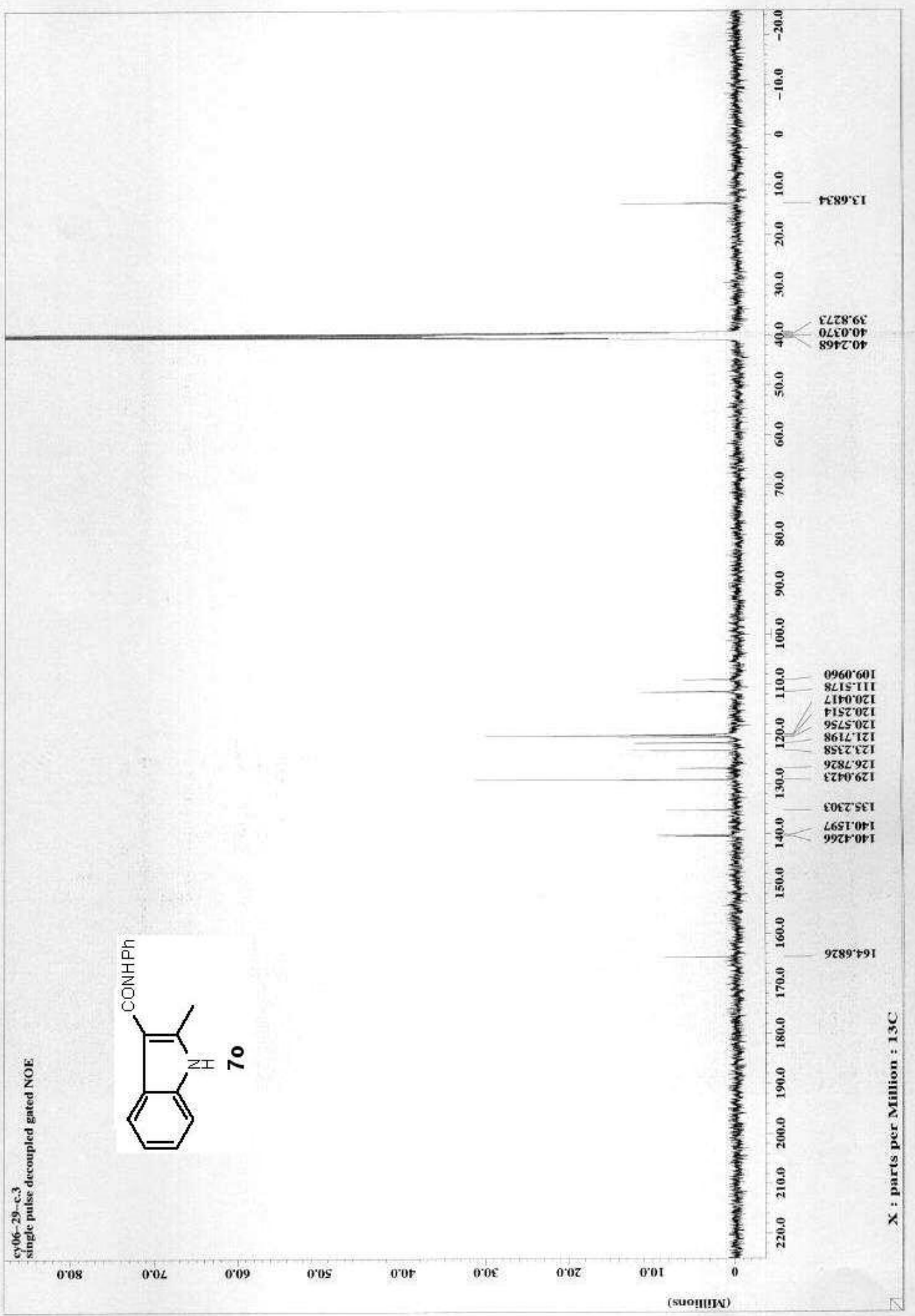




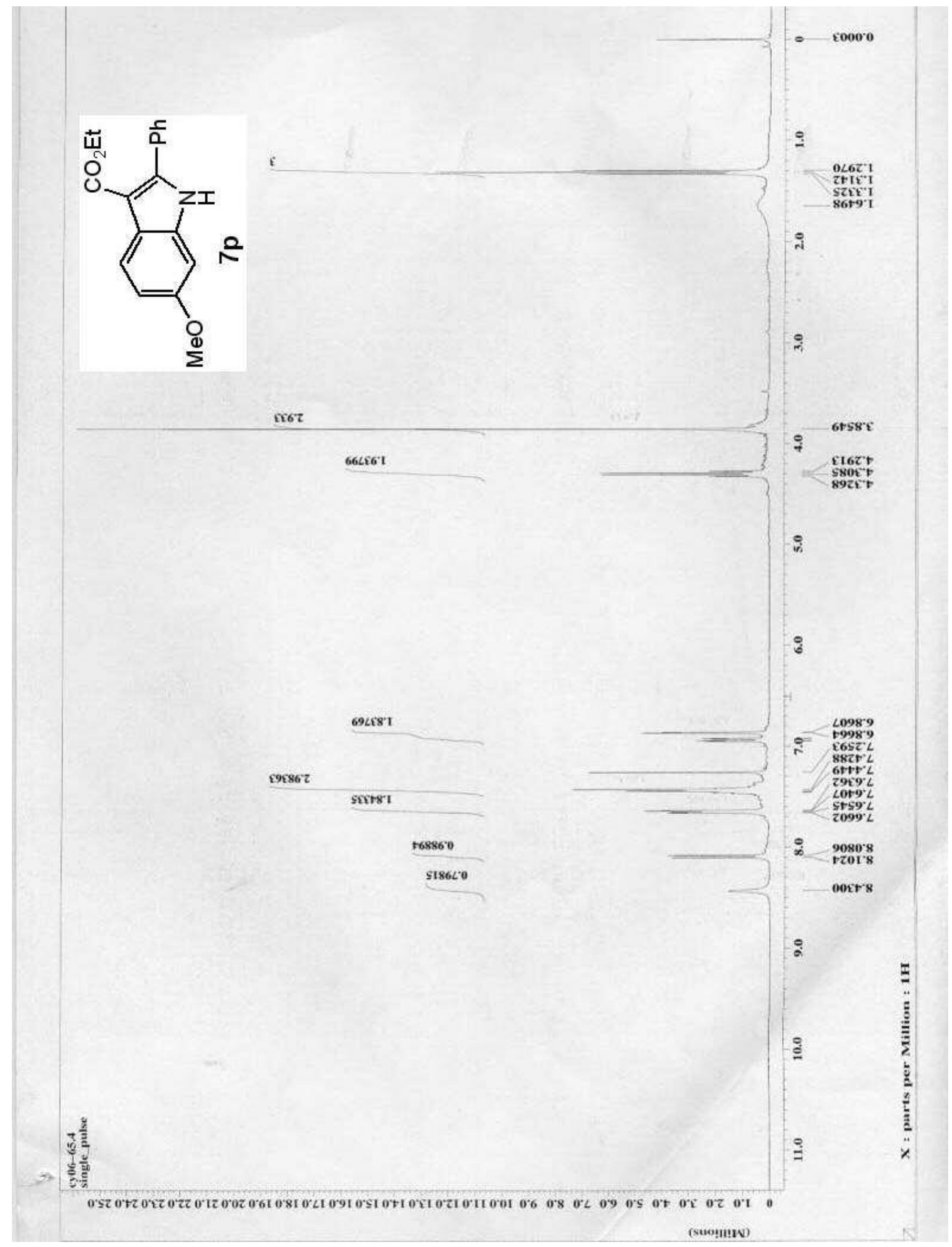




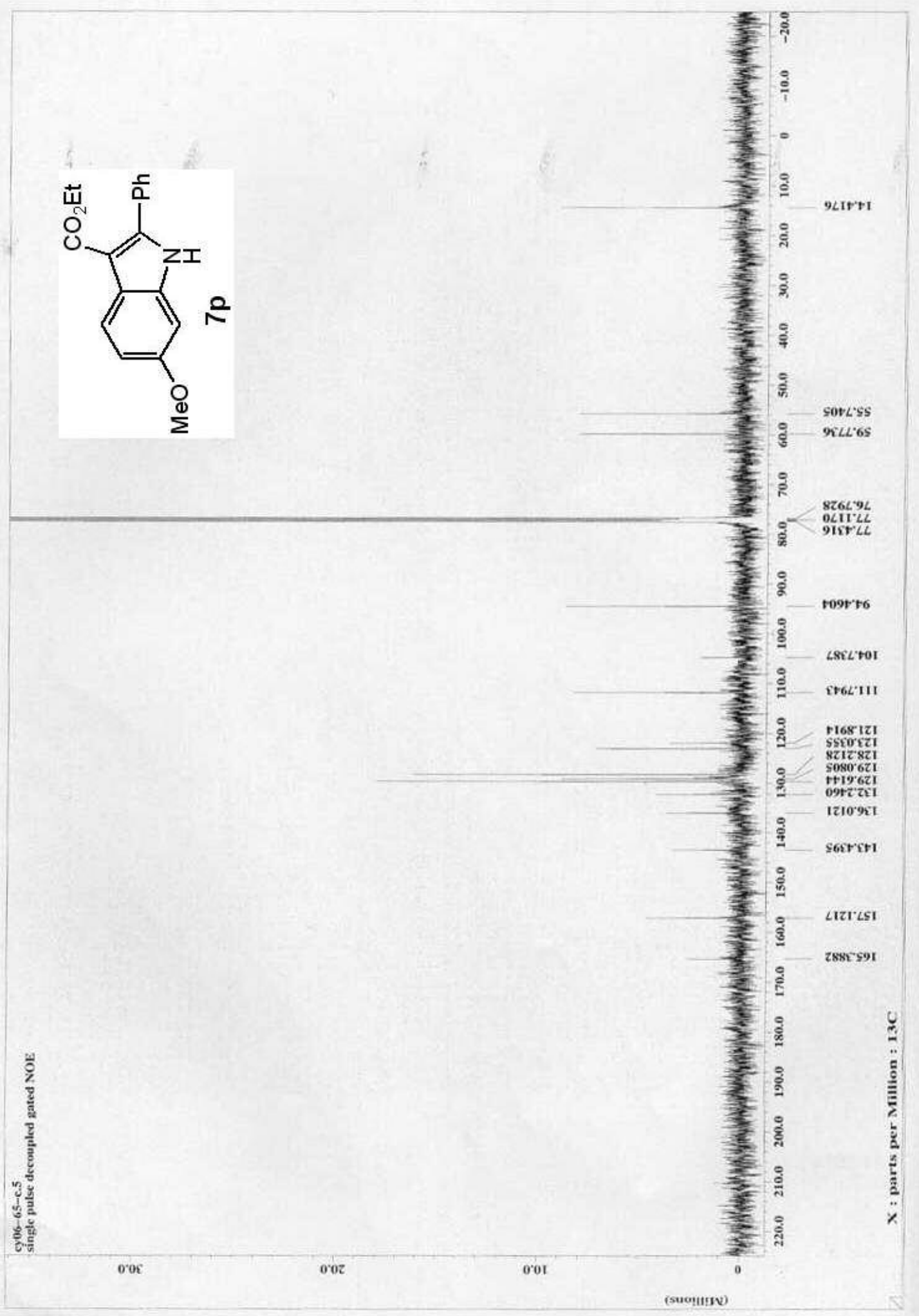




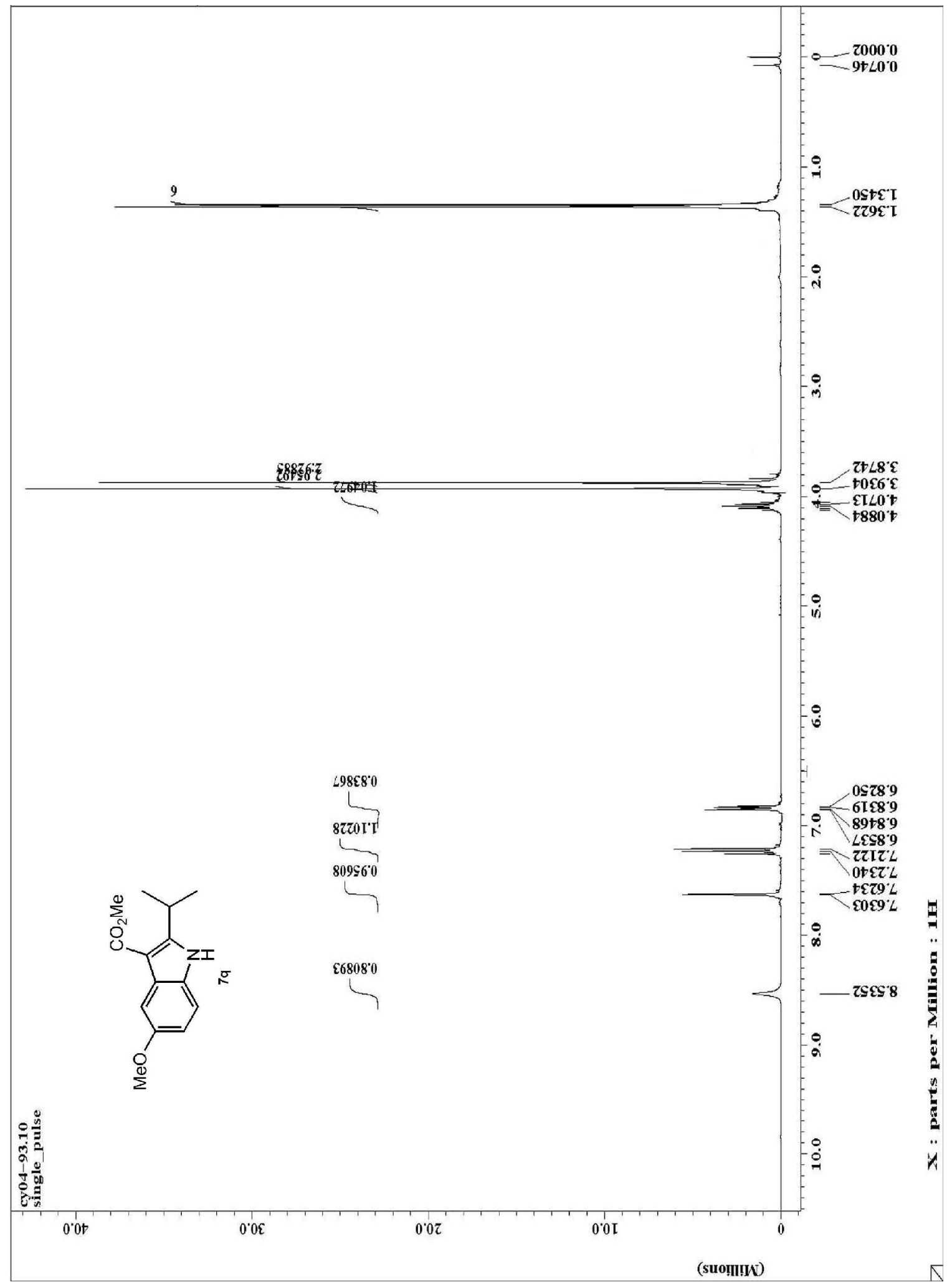


$\frac{5}{3}$

2812

?.6० 52

$\angle O L O S-$

[98 GS

I0L $\mathrm{G} L$

$020 . \angle L=$
Rer.

$03 \angle 201-\cdots$

$\angle G L E O H$

50t

वLL. $25 \mathrm{~T}=$

$\nabla \angle 0^{\circ} 821-$

GटE $625 \ldots$

$\checkmark 98$ EST-

B५9 $९ 9$..

IอE' 99 T

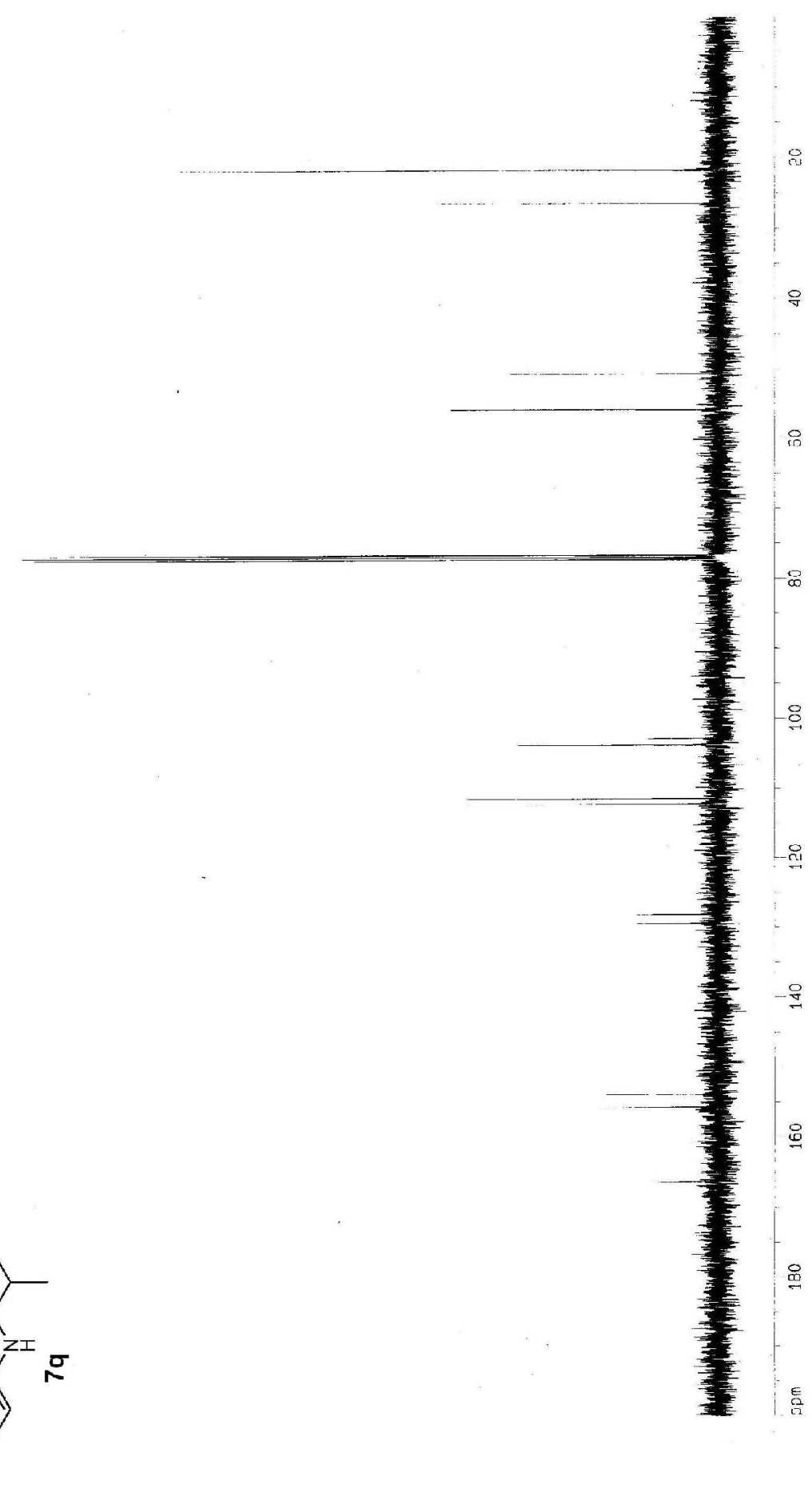




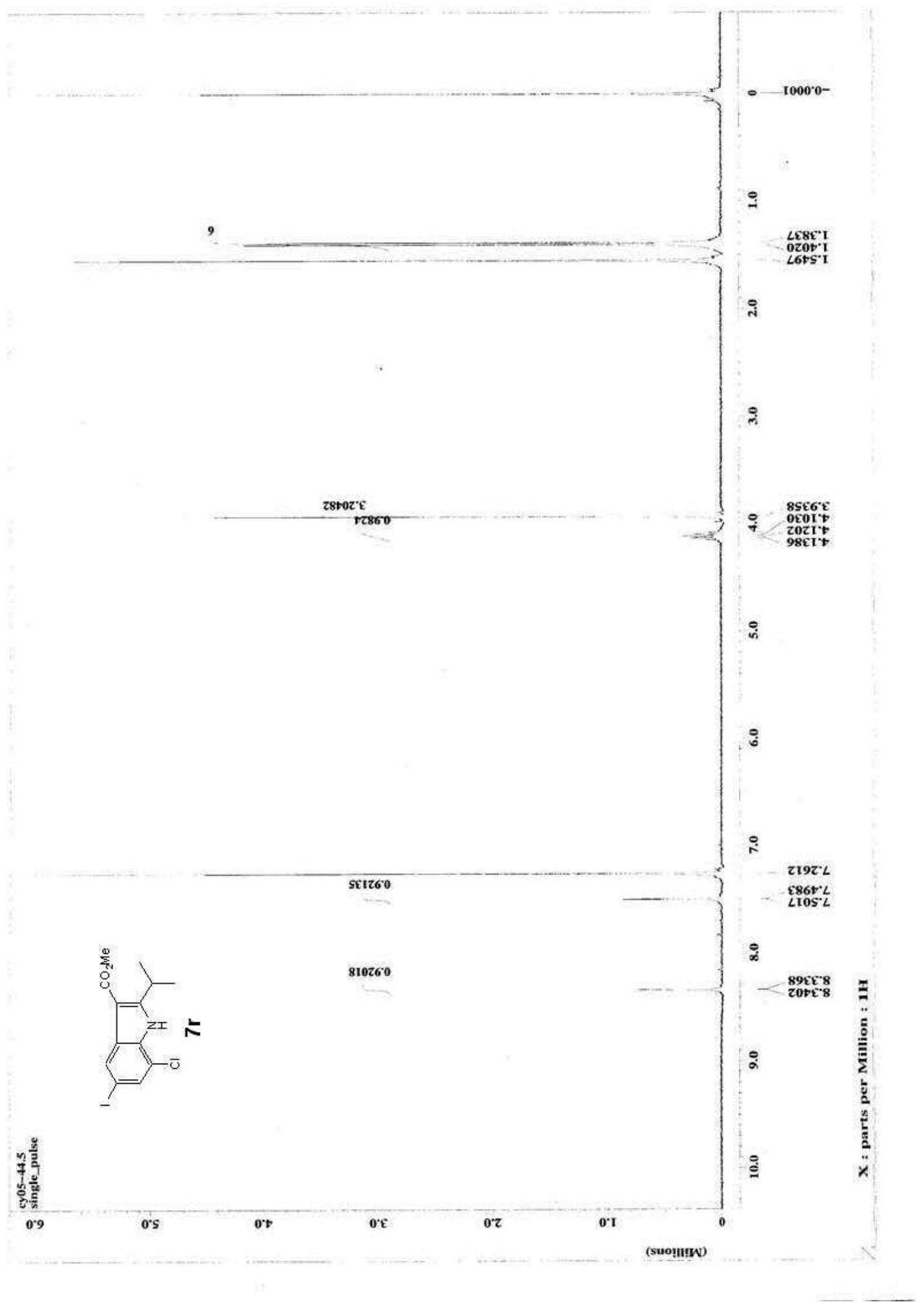


เย9. เว

$\varepsilon \angle E^{\prime} 92$

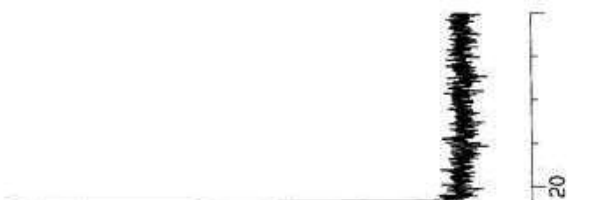

$280^{\prime}$ IS

$\angle 9 L ' 9 L$

$020 \angle L$

$919 \cdot 68$

ع8૬ ' $\varepsilon 0 \mathrm{-}$

$280 . \angle H$

051625

919 $621-$

GDC OEL -

6EO IEI-

OSG $\triangle 55$

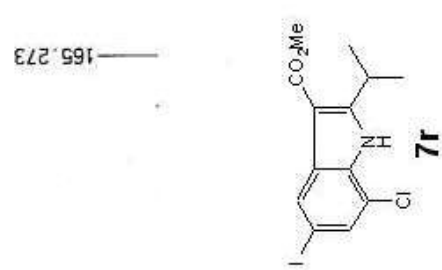




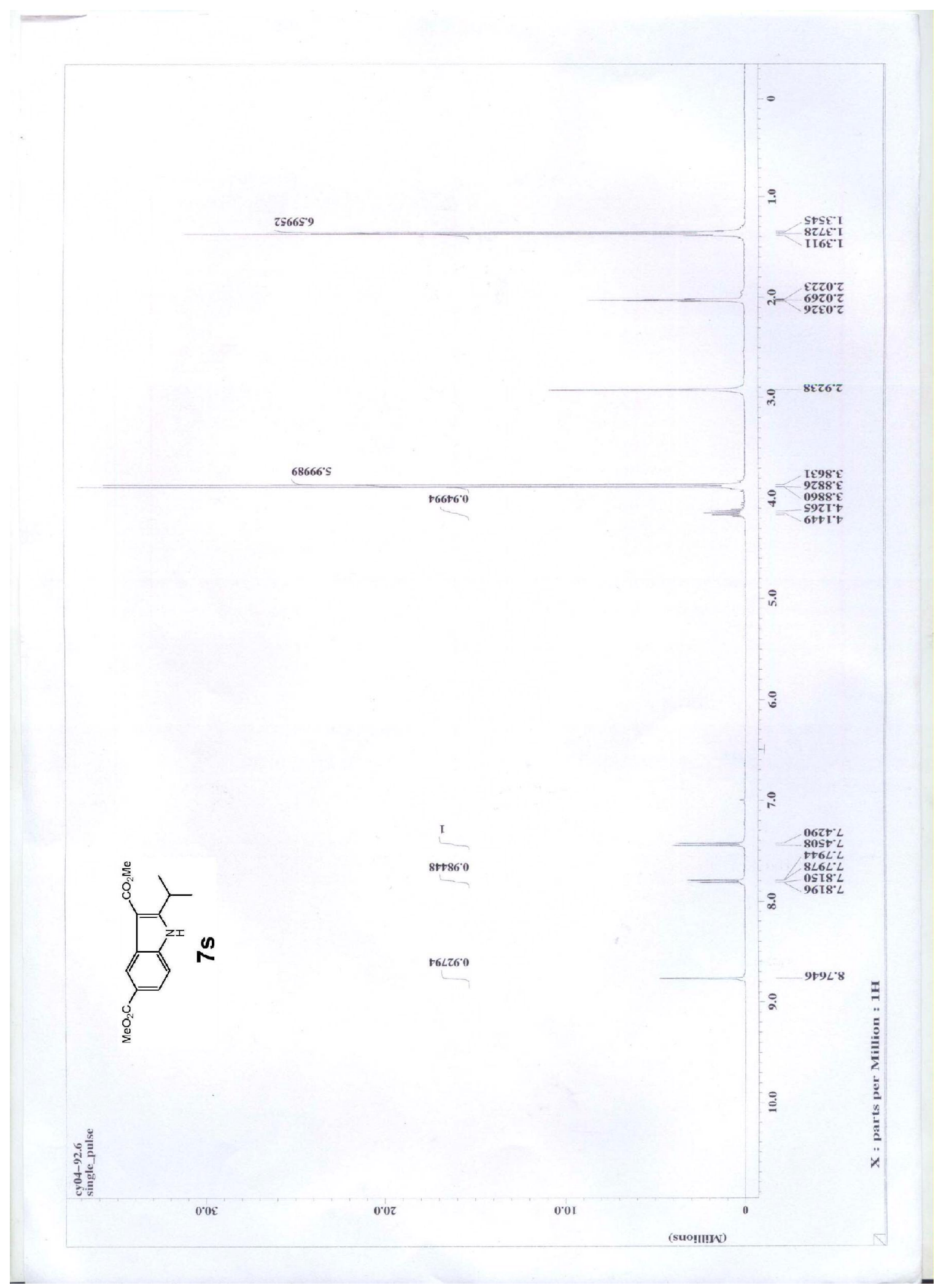


2
3
3
3

8681

yle $\mathrm{ll}$

Ue b

90952

$9 \mathrm{G} \angle \mathrm{b} 2$

J6E 62

टा! $0 \varepsilon$

$\angle E C C^{\circ} O E$

$\exists Б \mathrm{C}^{\circ} 0 \mathrm{\varepsilon}$

पदि $0 E$

GE6. $0 \mathrm{G}$

प 619

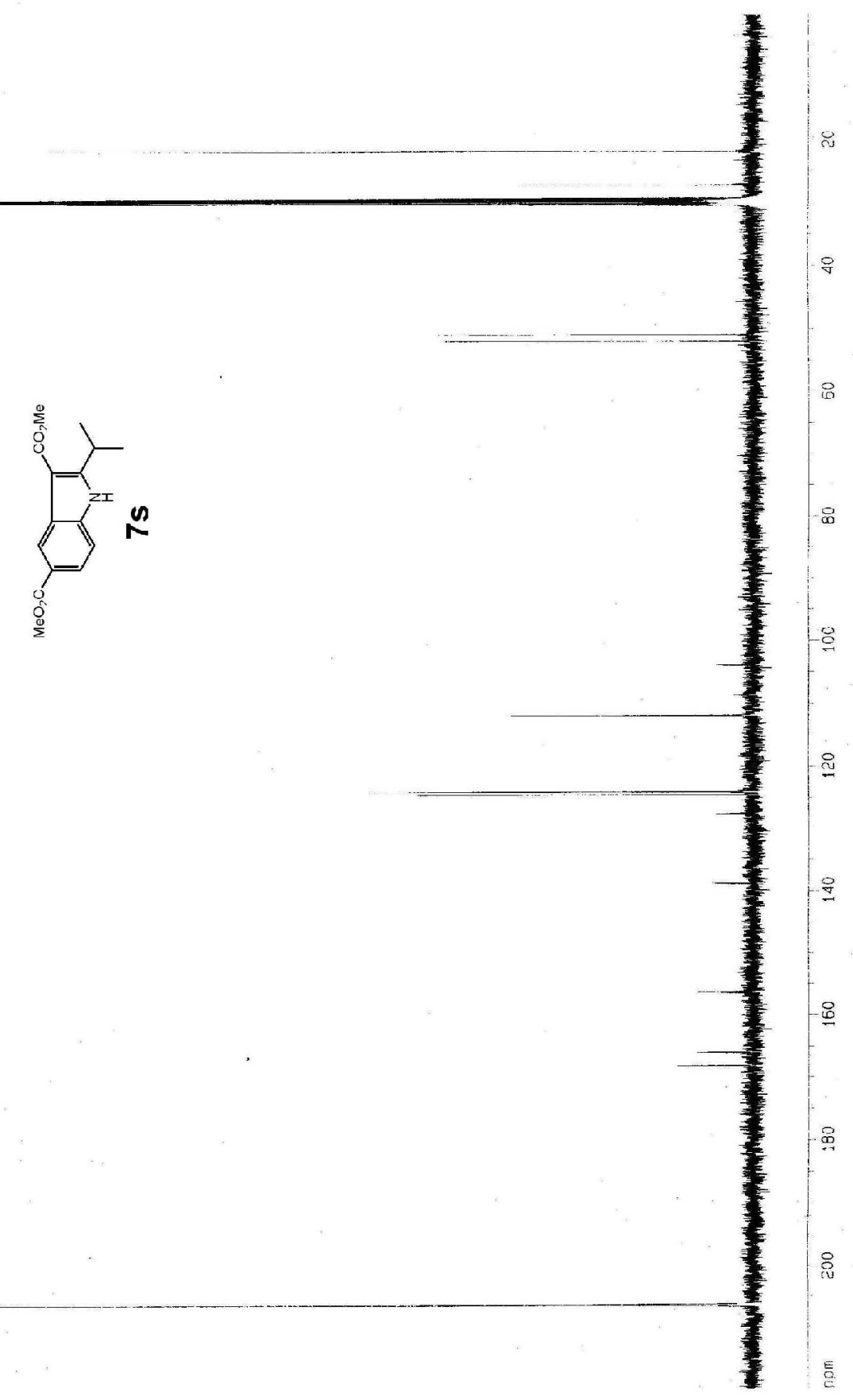

$950 \cdot 80$ L

GLG II -

0ट6 Uи

600 吔

$1 \angle 0^{\circ} V 2 I->$

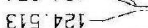

ब9व $\angle$ टा .

OGL gE I

टटट 955

780 $991-\ldots$
$65.89 t \ldots$

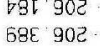




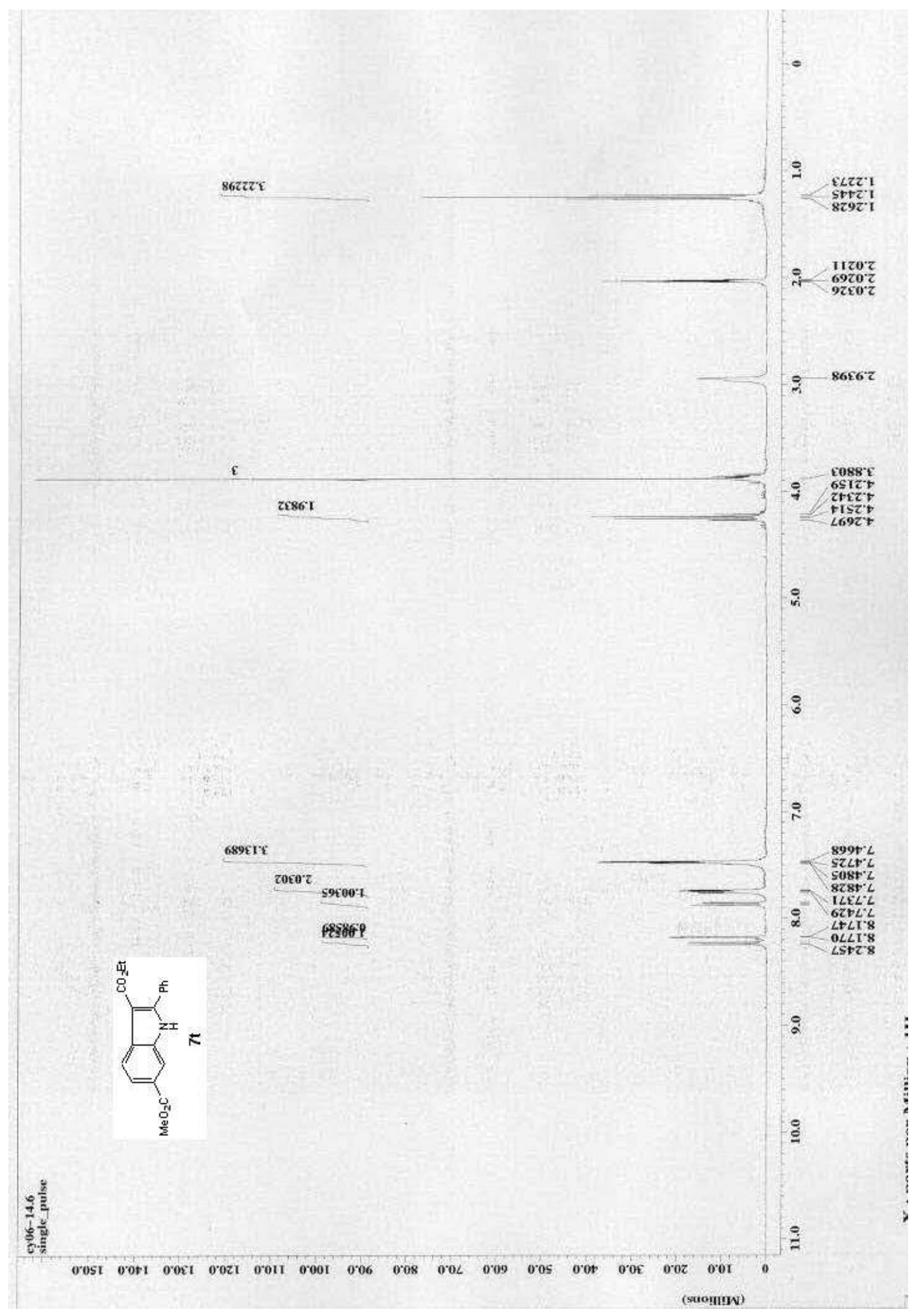




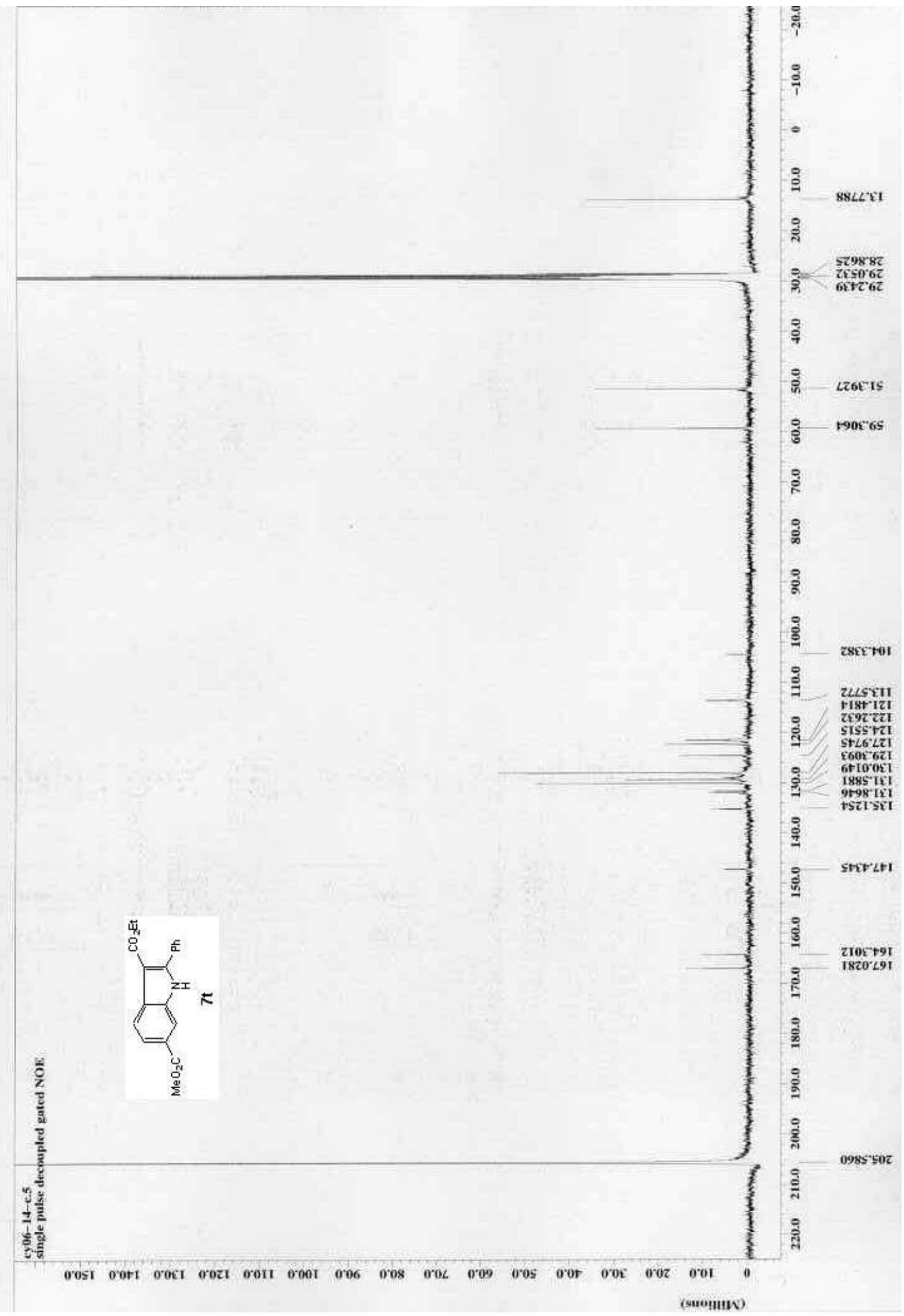




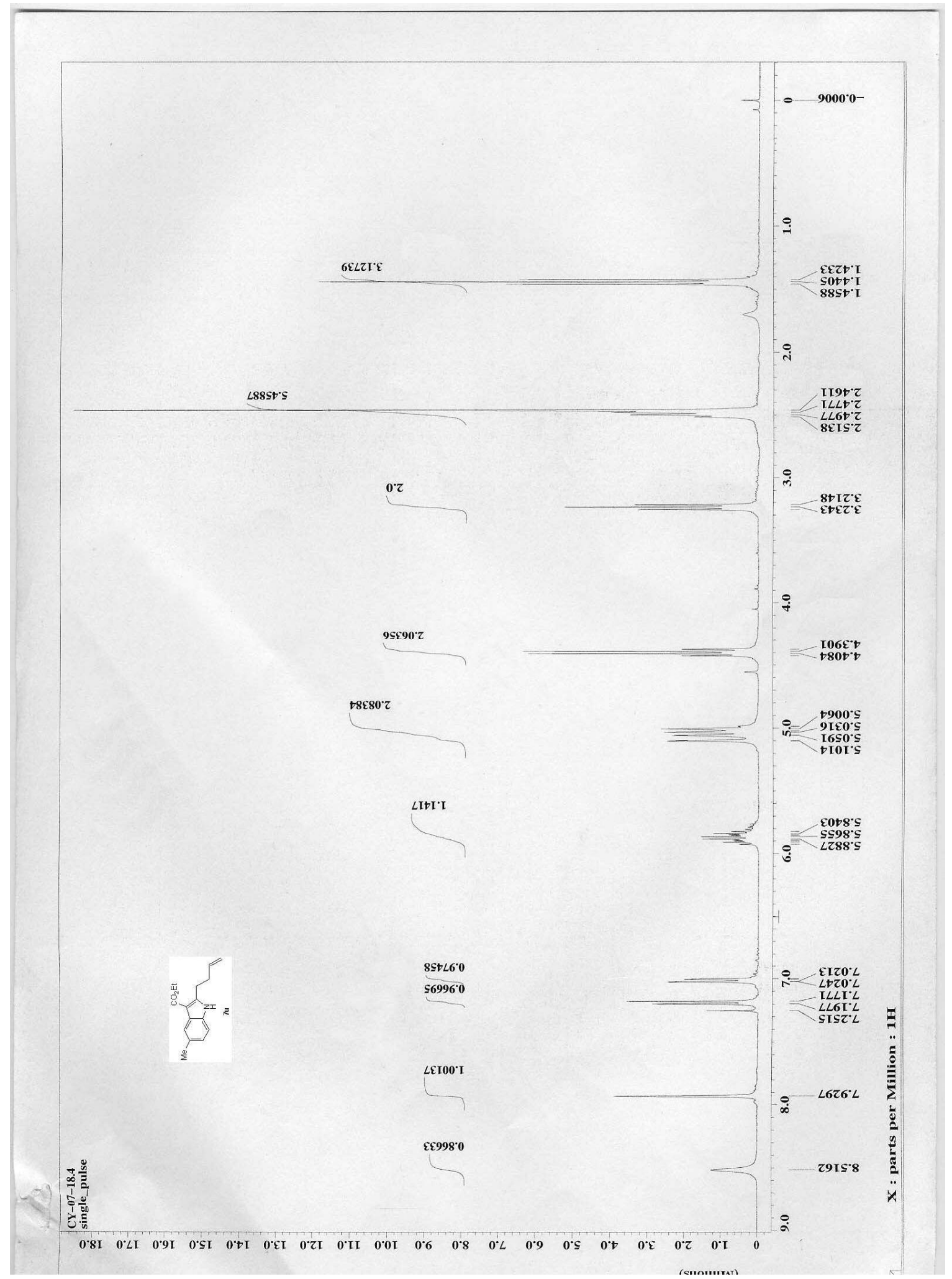




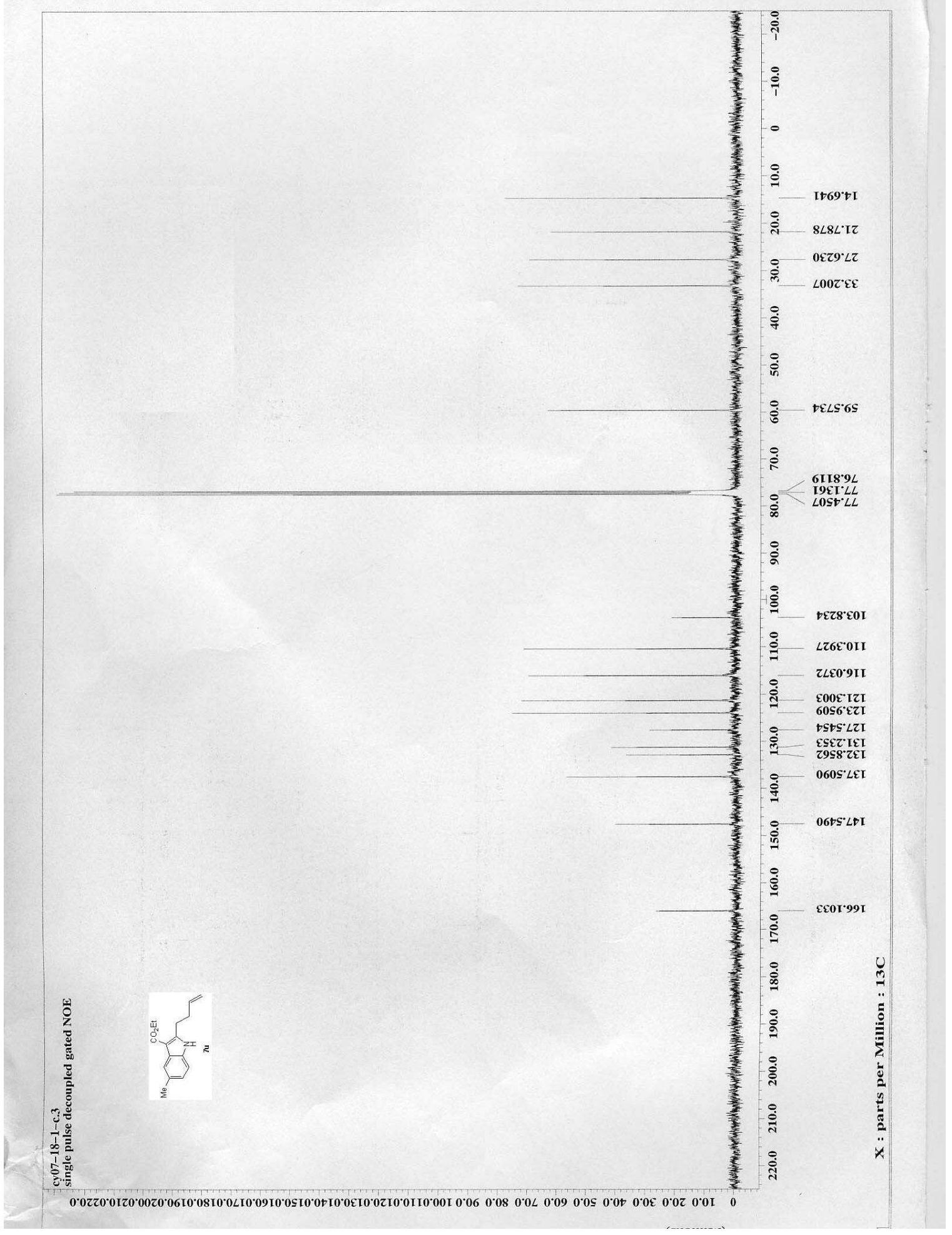




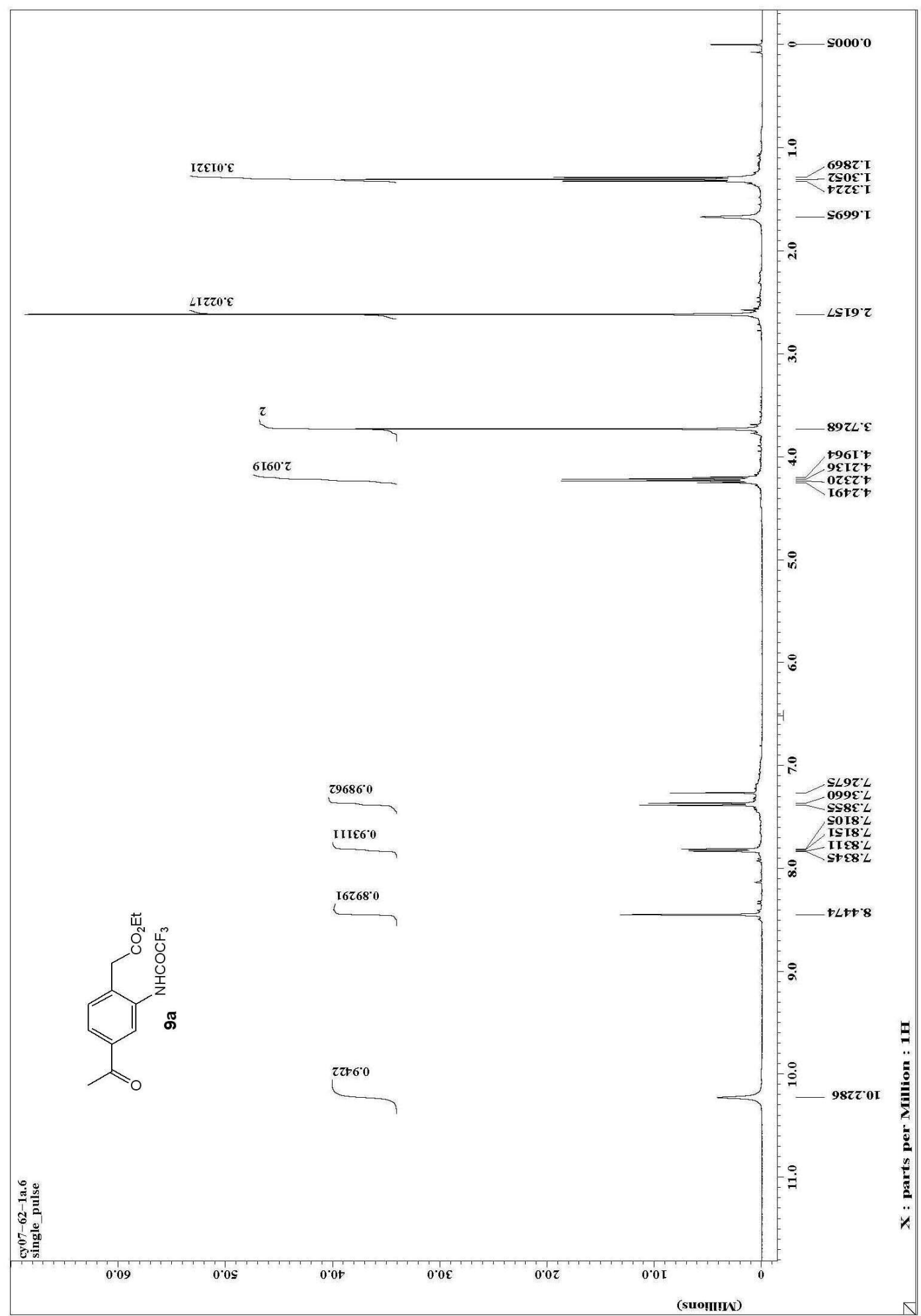




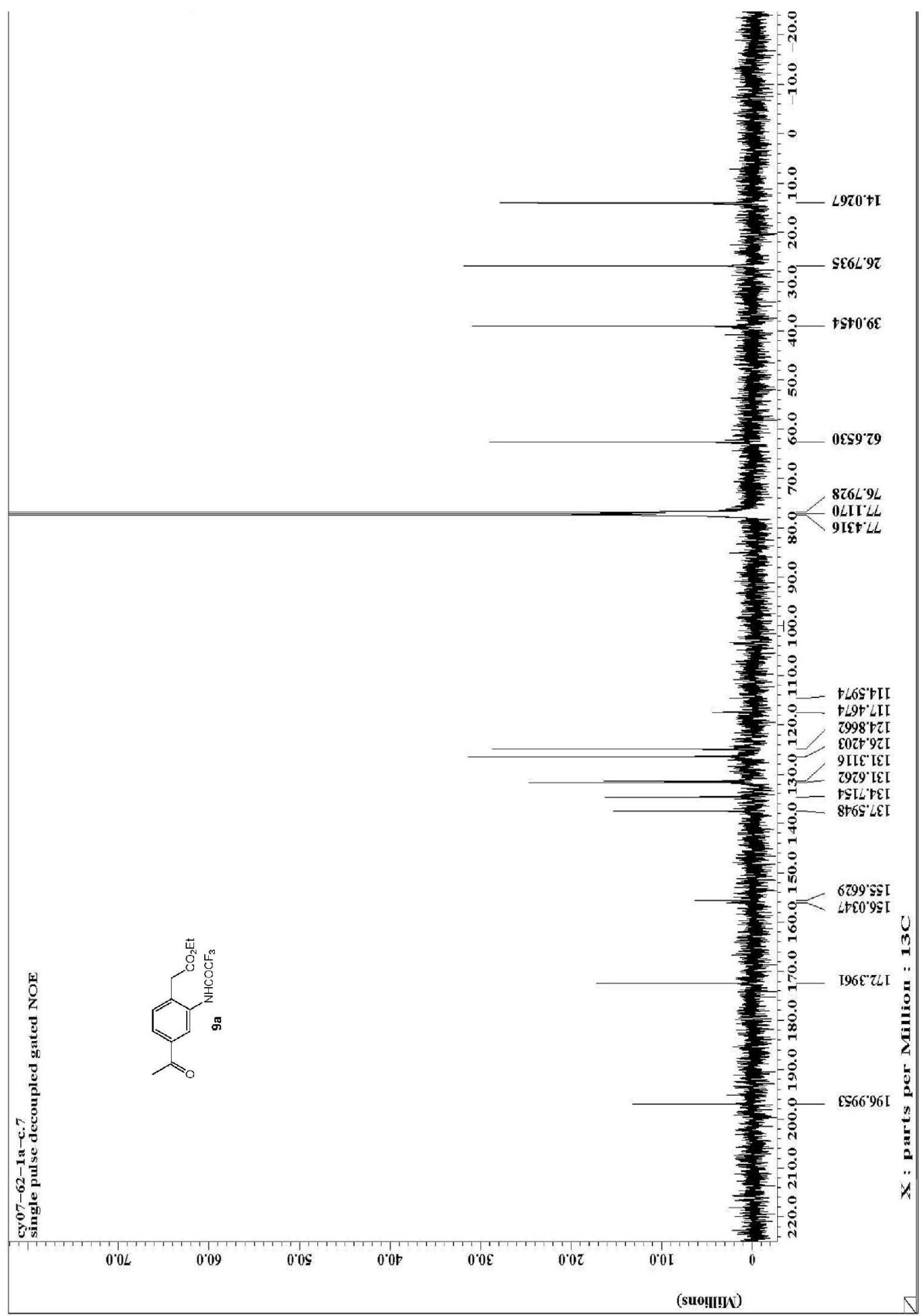




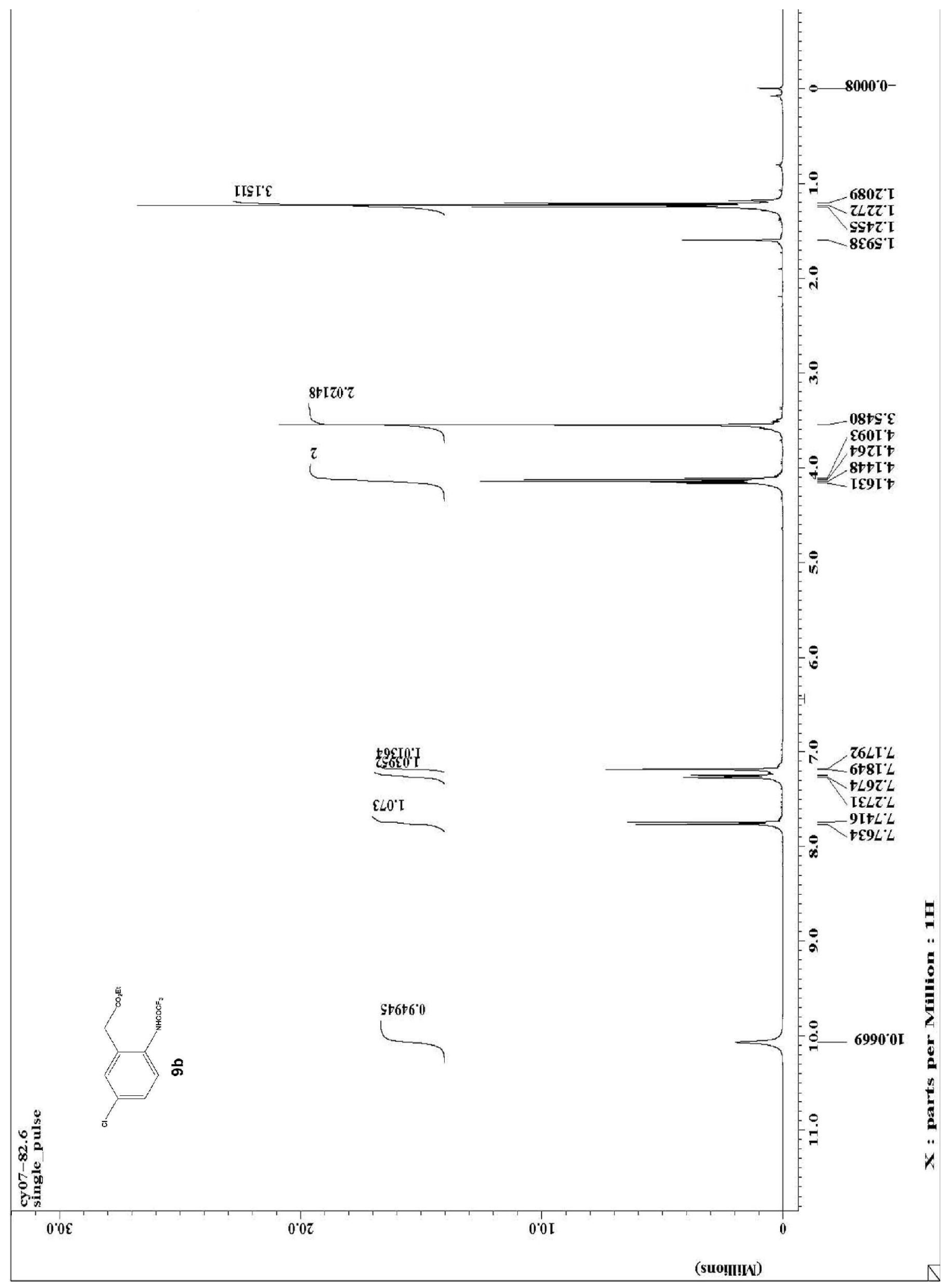




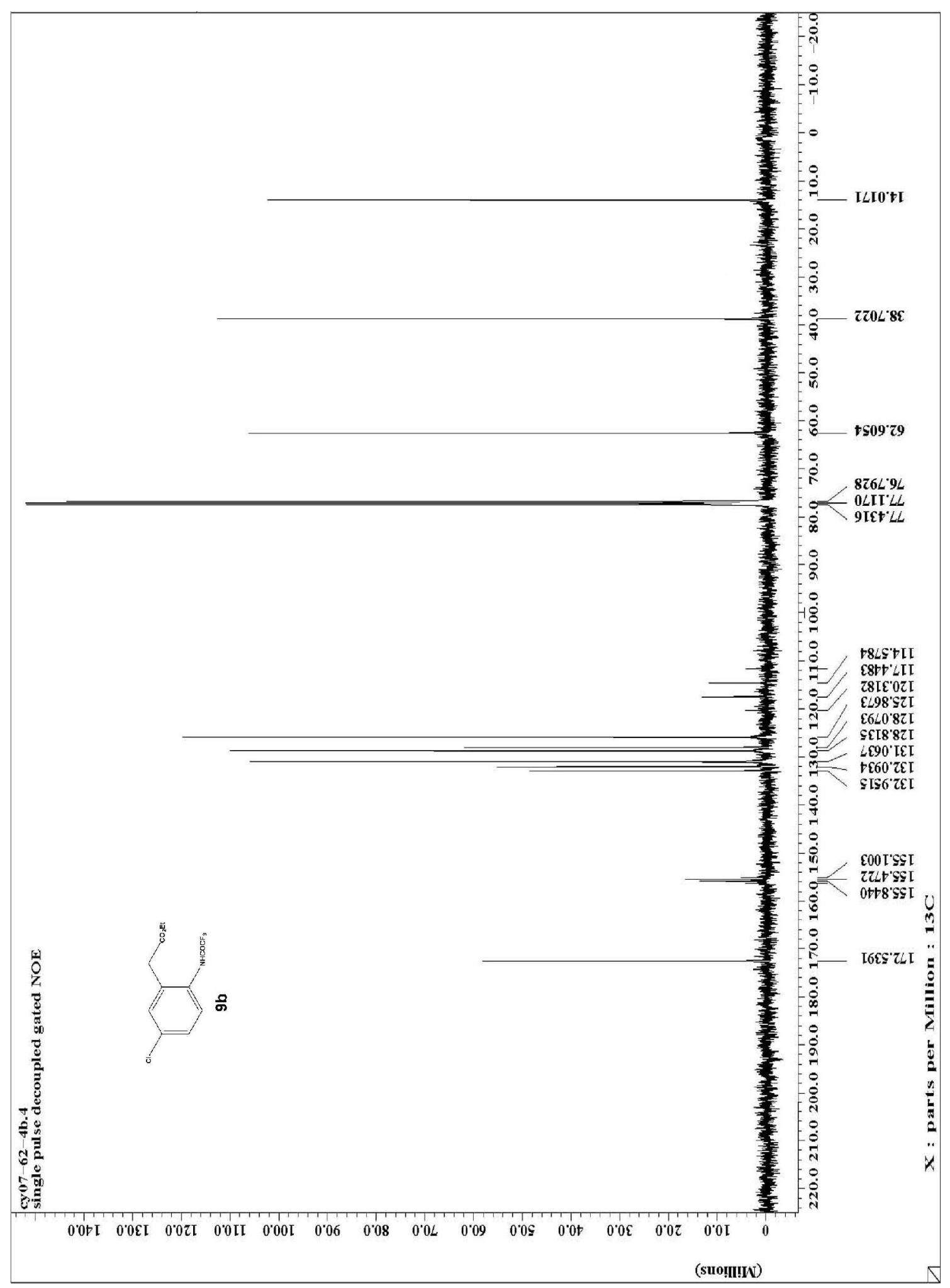

